\title{
The influence of terrestrial run off on marine biotic communities: An example from a thrust-top carbonate ramp (Upper Pennsylvanian foreland basin, Picos de Europa, NW Spain)
}

\author{
O. Merino-Tomé ${ }^{\mathrm{a}, *}$, Juan R. Bahamonde ${ }^{\mathrm{b}}$, E. Samankassou ${ }^{\mathrm{c}, \mathrm{d}, 1}$, E. Villa ${ }^{\mathrm{b}}$ \\ a Instituto Geológico y Minero de España, Parque Científico de León, Avda. Real, 1., Edificio 1, 24006 León, Spain \\ b Department of Geology, Oviedo University, Faculty of Geology, Arias de Velasco s/n, 33005 Oviedo, Spain \\ c Département de Géosciences, Géologie et Paléontologie, Université de Fribourg, Switzerland \\ d Dept. of Sedimentology and Marine Geology, Vrije Universiteit Amsterdam, 1081 HV Amsterdam, The Netherlands
}

\begin{abstract}
High-diversity marine biotic communities characterize the lower Kasimovian (Upper Pennsylvanian) carbonates of the Las Llacerias Formation in the Ándara Massif (Picos de Europa Province, Cantabrian Mountains, Spain). The carbonates accumulated on a small thrust-top ramp system. Within the shallow, lowenergy and euphotic realms, biotic communities were characterized by abundant photozoans (calcareous algae and cyanobacteria) and heterozoans including filter and suspension feeders (calcareous and siliceous sponges, bryozoans, brachiopods, crinoids), diverse other metazoans (rugose solitary and colonial corals, tabulate corals, bivalves, gastropods and echinoids), benthic foraminifers including very abundant small incrusting "tubiforms" and conspicuous swarms of cement-filled spheres (calcispheres or Penella). Smallsized buildups of chaetetid sponges, syringoporids, branching rugose corals, Anthracoporella and phylloid algae commonly developed in these shallow-water environments. Meanwhile, mud mounds formed at greater water depths, mostly below the lower limit of the phothic zone. The occurrence of such diverse biotic communities and the grain composition of the shallow-water deposits, not recorded in the platform-top successions of the antecedent Bashkirian-Moscovian carbonate shelf (Valdeteja and Picos de Europa formations) are interpreted as linked to increased nutrient levels (mesotrophic to mildly eutrophic conditions) in the actual sea-surface water. The nutrients are inferred to have resulted from land-derived fluxes from the rivers draining the adjacent growing Variscan Orogenic chain. Nutrients were subsequently transported into the narrowed marine shallowing foreland basin located in the eastern side of Pangea, within the palaeoequatorial humid belt. Comparison to the Pennsylvanian Auernig Group in the Carnic Alps allows the discrimination between the influence of land-derived versus upwelling-derived nutrients, providing a useful tool in the interpretation of biotic assemblages in the fossil rock record.
\end{abstract}

\section{Introduction}

Environmental factors, primarily water depth, light, temperature, salinity, oxygen level and nutrient supply, control the composition of carbonate rocks, as has been demonstrated in numerous studies during the last decades (Chave, 1967; Lees and Buller, 1972; Lees, 1975; Birkeland, 1977; Hallock, 1987; Carannante et al., 1988; Hallock, 1988; Hallock et al., 1988; Nelson, 1988; Carannante et al., 1997; Hallock,

\footnotetext{
* Corresponding author.

E-mail addresses: o.merino@igme.es (O. Merino-Tomé), jrbaham@geol.uniovi.es (J.R. Bahamonde), Elias.Samankassou@unige.ch (E. Samankassou),

evilla@geol.uniovi.es (E. Villa).

1 Present address: Section of Earth and Environmental Sciences, University of Geneva, rue des Maraîchers 13, 1205 Geneva, Switzerland.
}

2001; Mutti and Hallock, 2003; Vecsei, 2003; Halfar et al., 2004; Pomar et al., 2004; Wilson and Vecsei, 2005; Halfar et al., 2006). The biotic associations and non-biogenic composition of carbonate rocks thus represent good proxies for the reconstruction of environmental parameters (James, 1997; Hallock, 2001; Mutti and Hallock, 2003; Pomar et al., 2004; Schlager, 2005).

Current models aiming at classifying and interpreting carbonate rocks therefore are based, among the most important criteria, on the biotic and non-biogenic grains. However, if using a single parameter, the interpretation may be biased by the fact that some physical parameters are closely linked and, thus, difficult to dissociate in the rock record. For example, nutrient supply and temperature may leave similar records in biogenic composition (Mutti and Hallock, 2003; Pomar et al., 2004; Halfar et al., 2006). Also, palaeoceanographic factors may influence the composition of carbonates and, possibly, lead to strange-appearing cases (Lavoie, 1995; Lukasik et al., 2000; 
(A)
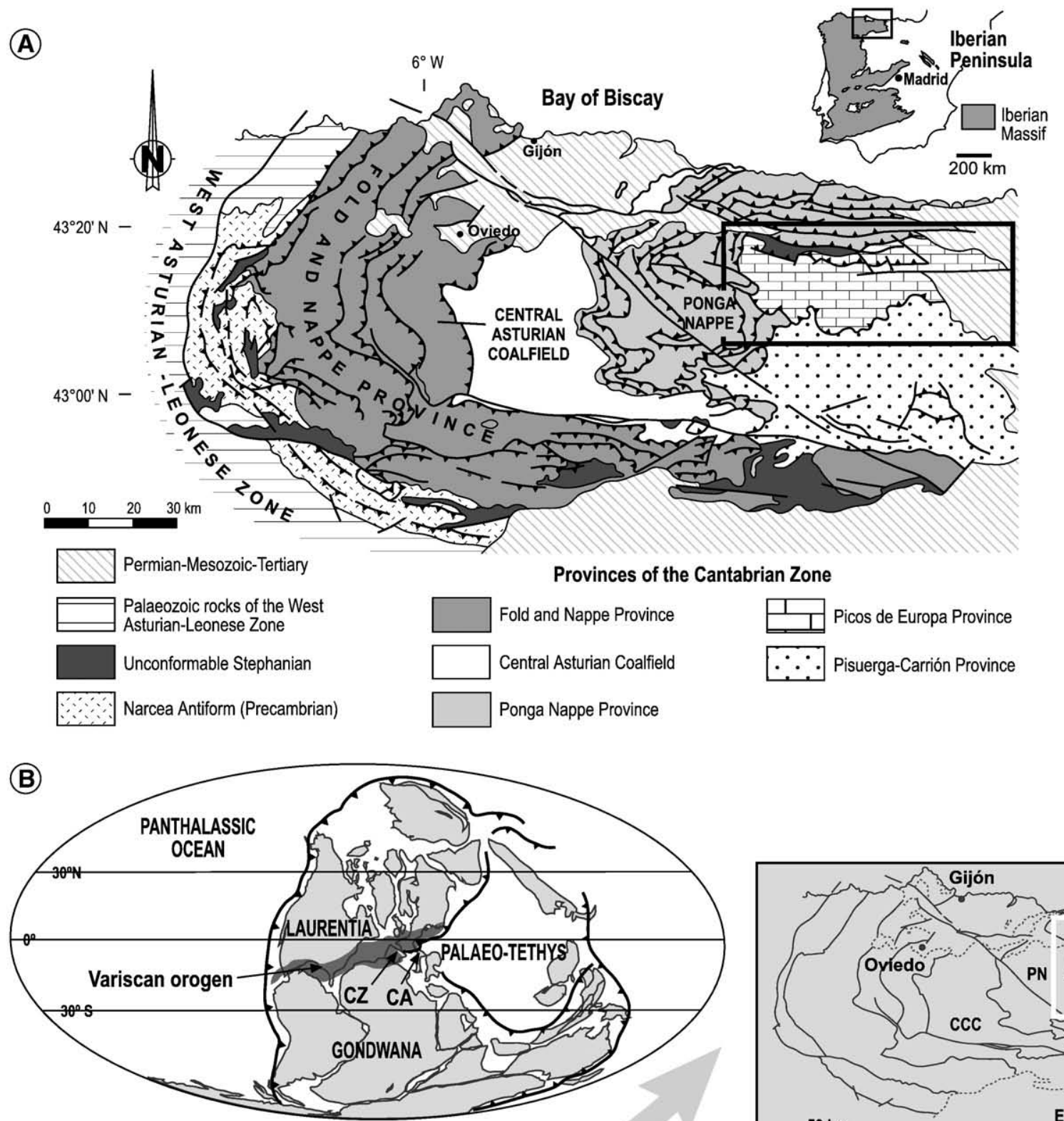

Pennsylvanian (306 Ma)
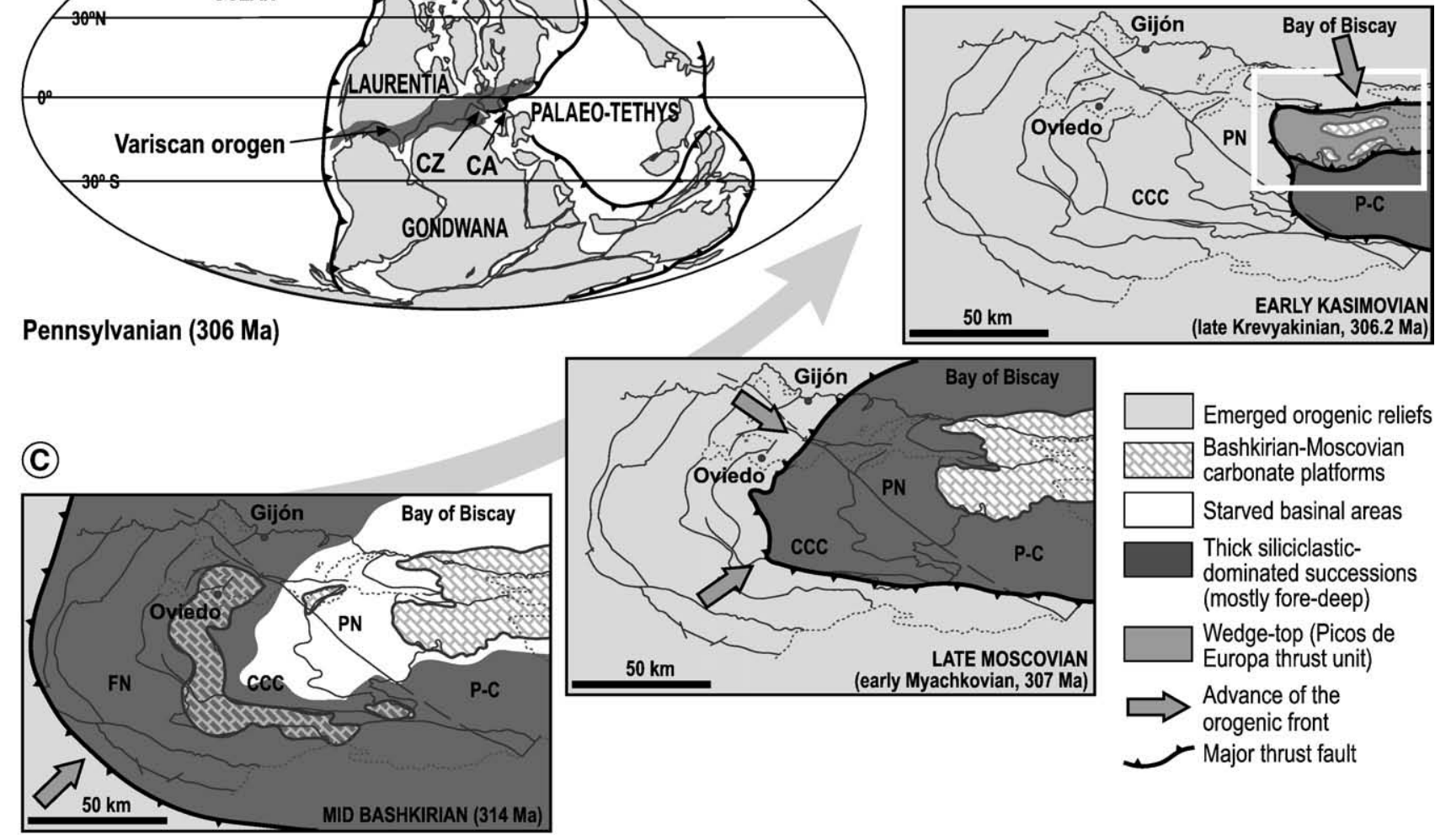

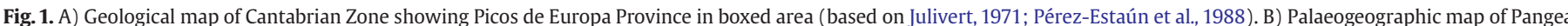

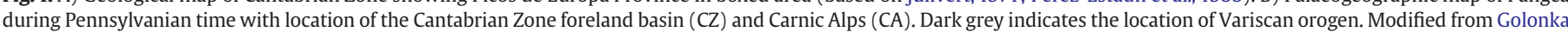

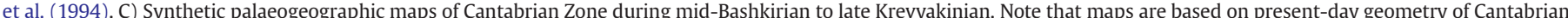
Zone and, thus, the significant tectonic shortening (nearly 50\%) in E-W and N-S direction resulting from Variscan thrusting is not considered. 
(A)

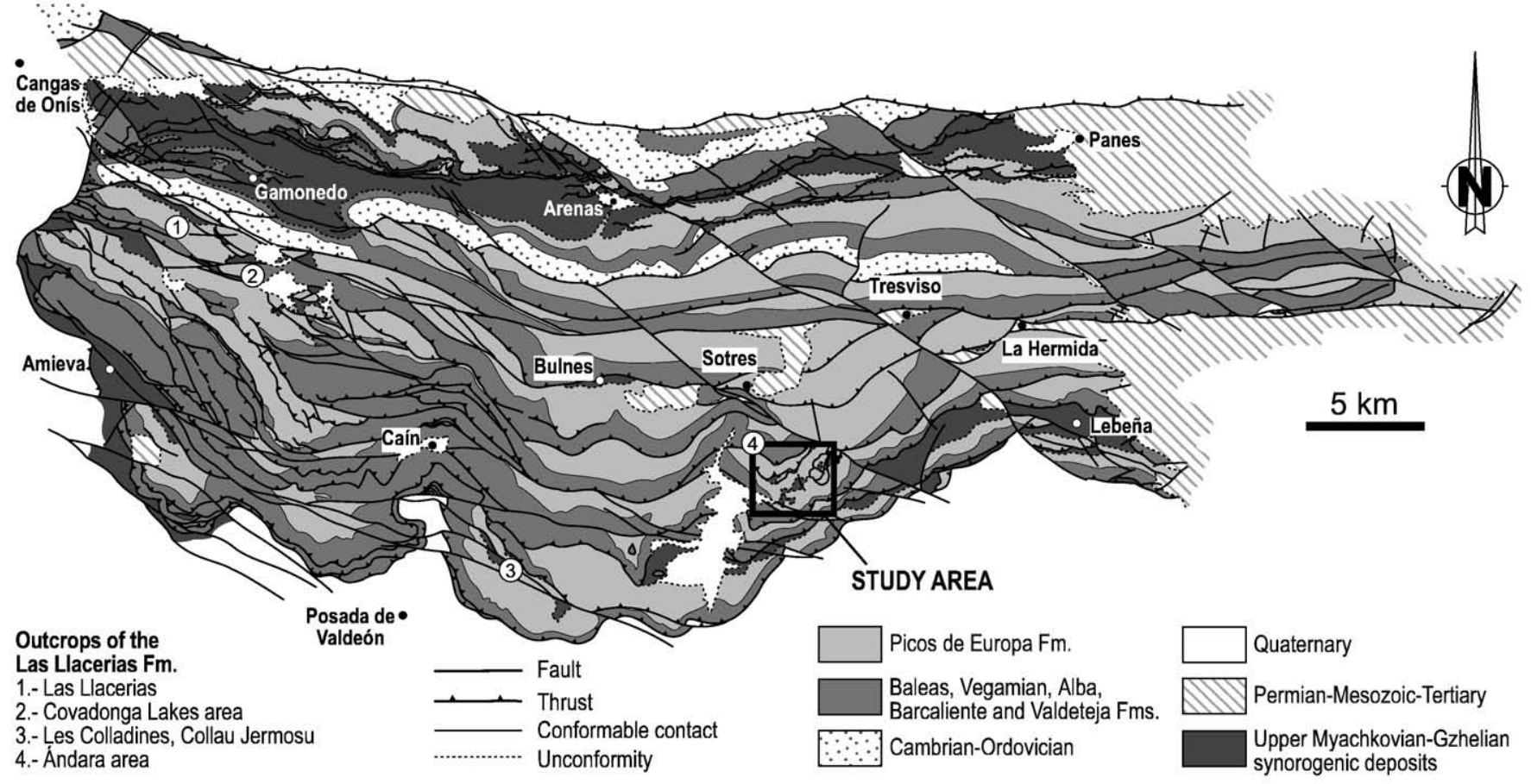

(B)

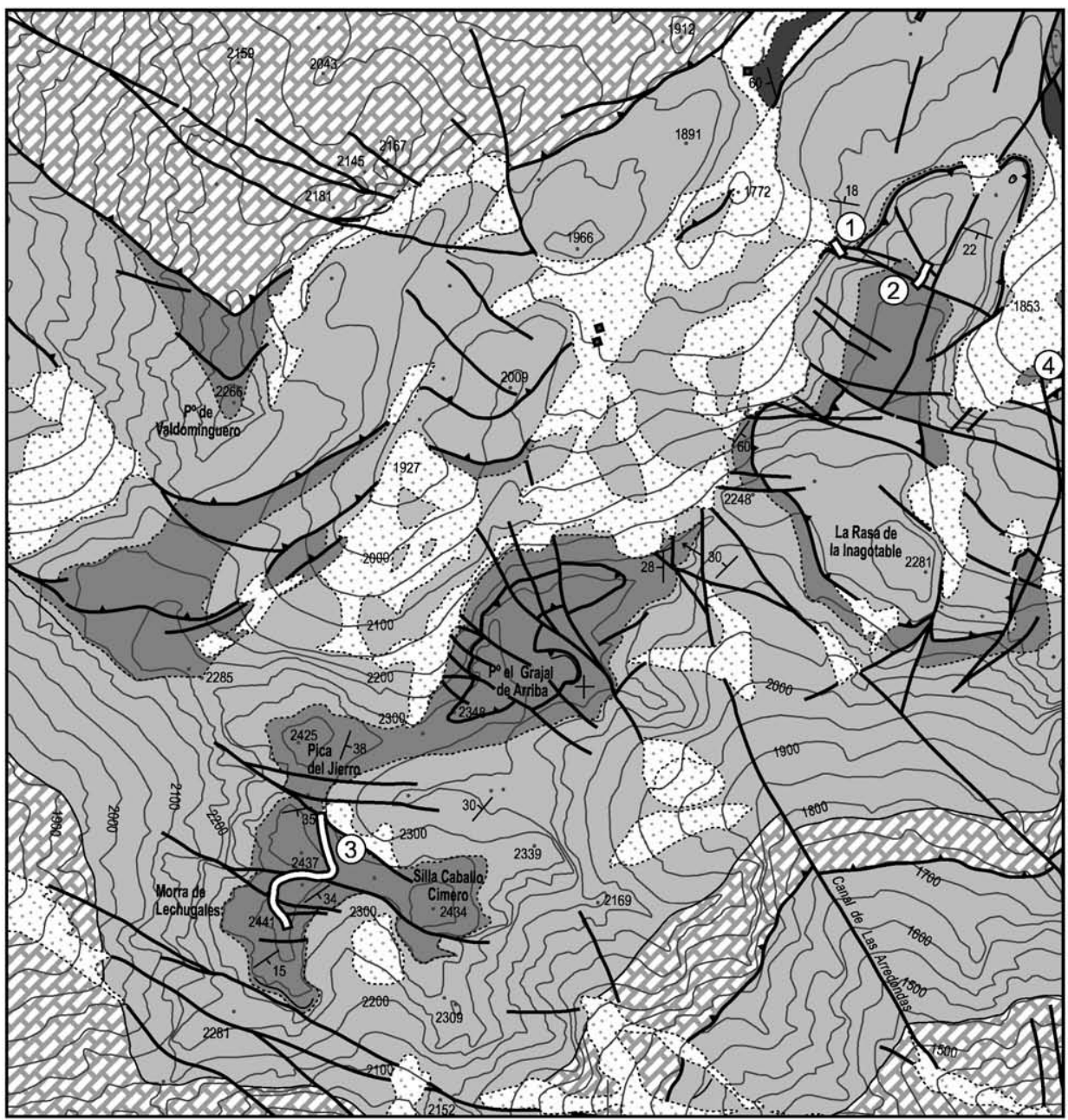

Fault

- - - Deduced fault

ᄂ Variscan thrust Unconformity

Conformable contact

(3) Stratigraphic section

$\therefore$ Quaternary deposits

Calcareous conglomerates and breccias (Upper Kasimovian-Gzhelian)

Massive dark shales with scattered intercalations of calcareous deposits (Kasimovian)

Las Llacerias Fm.

Valdeteja and Picos de Europa Fms. (Lower Baskhirian-Lowermost Kasimovian)

2 Baleas, Alba, Barcaliente Fms. (Tournaisian-Lower Baskhirian)

\section{Stratigraphic sections}

1.- Traviesas section

2.- Castillo del Grajal section

3.- Morra de Lechugales section

4.- Vegas de Ándara section

500

$1000 \mathrm{~m}$

Fig. 2. A) Synthetic geological map of Picos de Europa Province with location of study area (modified from Marquínez, 1989). B) Detailed geological map of Ándara area showing location of stratigraphic sections of Las Llacerias Formation included in Fig. 4. 
Samankassou, 2002; Wilson and Vecsei, 2005; Coffey and Read, 2007). Moreover, nutrients may derive from either upwelling or continental runoff, making the reconstruction questionable if the overall context is not well understood (Coffey and Read, 2007).

The example documented in the present paper demonstrates how knowledge of the overall tectonic context may help in deciphering palaeoecological factors. Highly diverse biotic associations occur within the Kasimovian (late Pennsylvanian) carbonate ramp deposits of Las Llacerias Formation in the Ándara Massif (Picos de Europa, Northern Spain), which unconformably overlies Bashkirian-earliest Kasimovian shelf limestones. The benthic communities that flourished on these ramps were not recorded in the previous carbonate platform. The area lacks evidence of coastal upwelling during deposition in early-mid Kasimovian time. Knowledge of the tectonic setting and the geodynamic reconstruction in an overall biostratigraphically wellconstrained context allow recognition of the siliciclastic input related to land-derived runoff as the main driving factor controlling the biotic association encountered. Comparisons are made to distinct intervals in the Pennsylvanian deposits of Carnic Alps (Austria-Italy), where the influence of terrigenous input and upwelling can be discriminated.

\section{Geological setting}

The Cantabrian Zone (NW part of the Iberian Massif) comprises a thick succession of Palaeozoic rocks mostly deformed by thin-skinned tectonics during the Variscan orogeny (Upper Devonian-Pennsylvanian) (Pérez-Estaún et al., 1988; Fig. 1A). During the Pennsylvanian, the Cantabrian Zone consisted of a marine foreland basin located at an equatorial position on the eastern coast of Pangea (Fig. 1B, C), with a pronounced asymmetric profile (Colmenero et al., 2002). In the distal part of this basin (the Picos de Europa and northern Ponga provinces), a large microbial boundstone-dominated carbonate platform developed (Bahamonde et al., 2000; Bahamonde et al., 2007) from Bashkirian to early Kasimovian times (Fig. 1C). Initially, the carbonate platform prograded into a starved marine basin, which was gradually filled and narrowed due to the sediment input from the orogen and the forward advance of the deformation.

The migration of the orogenic front towards the foreland during the last stages of the Variscan orogeny (late Pennsylvanian) led to the progressive deformation of the carbonate platform. During the Moscovian-Kasimovian transition, the northern domain of the platform (Ponga-Cuera area) and northern sectors of the Picos de Europa Province were incorporated into the orogenic wedge and cut by a set of E-W-oriented thrust nappes emplaced southwards (Merino-Tomé, 2004; Merino-Tomé et al., 2009). From the early Kasimovian (early Krevyakinian-Khamovnikian), the advance of the tectonic deformation slightly affected the remaining carbonate platform (central and southern part of the Picos de Europa Province), giving rise to elongated uplifted areas approaching to sea-level surface that consisted of growth structures related to blind thrusts. The subaerially exposed part of the previous carbonate deposits was partially eroded, whereas carbonate production persisted in the remaining shallowwater areas, actually forming narrow ramp-like carbonate platforms. The emergence of uplifted areas bordering the Picos de Europa Province led to input of abundant siliciclastics into this sector of the marine foreland basin, which has remained free of terrigenous input during most of the Carboniferous time. In the central and southern part of the Picos de Europa Province these siliciclastics accumulated in deep restricted troughs in between the aforementioned carbonate ramps (Merino-Tomé, 2004; Merino-Tomé et al., 2009).

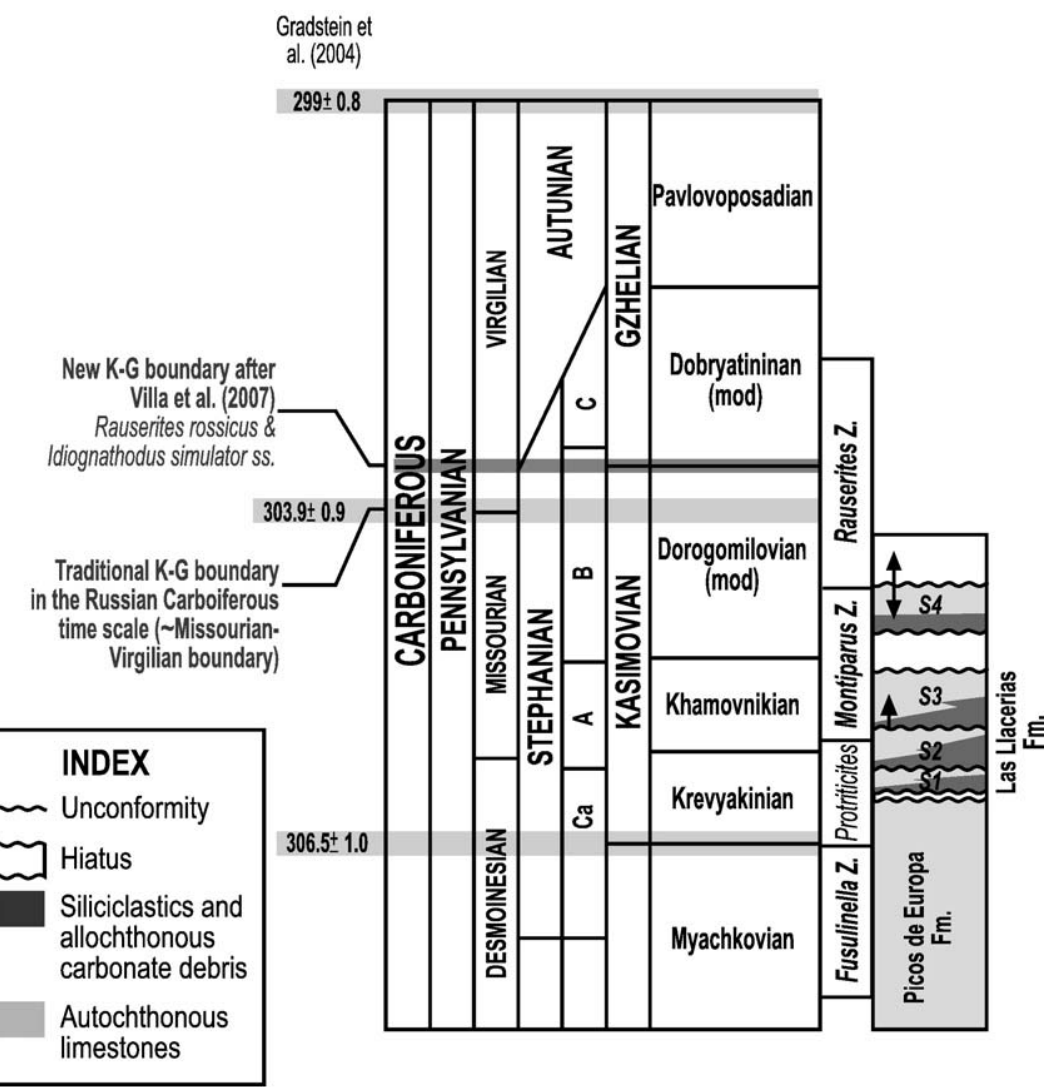

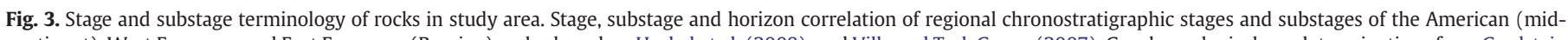

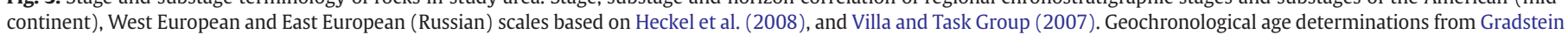
et al. (2004). 
3. Lower Kasimovian (Krevyakinian-Khamovnikian) carbonate successions of the Picos de Europa Province

The Las Llacerias Formation (Martínez García and Villa, 1999) is a dark coloured, marly calcareous succession, locally up to $190 \mathrm{~m}$ thick that unconformably rests on the Picos de Europa Formation (Moscovianearly Kasimovian). In the stratotype section (NW sector of the Picos de Europa Province), the Las Llacerias Formation is Khamovnikian in age (Cózar et al., 2007), but span from late Krevyakinian to Khamovnikian in other outcrops such as the Covadonga Lakes (toward the N), Ándara and Les Colladines-Collau Jermosu (in the S), and in the easternmost exposures of the carbonate complex (Figs. 2 and 3 ).

This paper deals with the Las Llacerias Formation strata in the SE border of the Picos de Europa Province (Ándara massif) (Fig. 2B). The outstanding exposures have allowed us to undertake a sedimentological study of the succession, including: (1) detailed geological mapping at scale $1: 25.000$, (2) measurement and logging of stratigraphic sections, (3) field description of lithofacies and sampling for microfacies analysis (4) sampling for biostratigraphy (fusulinoideans) and (5) study of the biotic associations.

\section{Stratigraphy of the Las Llacerias Formation in the Andara area}

The Las Llacerias Formation in the study area comprises 3 sequences, bounded by angular unconformities, which range in age from mid Krevyakinian (van Ginkel and Villa, 1999) to Khamovnikian (lower-mid Kasimovian, Upper Pennsylvanian, see Fig. 3). Each sequence consists of two stratigraphic intervals (Figs. 4-6):

1. The lower interval contains abundant calcareous clastics (calcareous breccias, minor conglomerates, calclitites and bioclasticintraclastic grain- to packstones) with some minor siliciclastics. These deposits usually display rapid lateral changes in thickness and distally interfinger with dark shales. Intercalated marls, and marly mudstones to wackestones contain abundant brachiopods, corals (Cyathaxonia sp.), bryozoans, crinoids and gastropods.

2. The upper interval is dominated by autochthonous carbonate deposits showing a conspicuous dark colour. Metre- to decametrethick packages composed of poorly-bedded, black nodular skeletal marly wackestones to packstones with a very rich and diverse biotic content occur at distinct intervals in sequences 1, 2 and 3 (Figs. 5 and 6). They include phylloid and Anthracoporella algal mounds and reef-mounds of chaetetid sponges (exclusive from sequence 1), syringoporids and colonial rugose corals. At certain levels, sphinctozoan sponges, brachiopods, bryozoans and crinoids are very abundant.

\section{Sedimentology of the Las Llacerias Formation}

The Las Llacerias Formation includes 14 lithofacies that are extensively described in Table 1 . These lithofacies are grouped in two main types of facies associations, namely clastic and autochthonous carbonates. Clastic carbonates (lithofacies G, Te1, Te2, and S) represent submarine breccia-slope aprons, and graded rudstone-topackstone tempestites accumulated in sub-wave base settings where locally carbonates also formed (facies B3). Autochthonous carbonates have been grouped according gross lithology and degree of winnowing into three facies associations using the classification scheme of Burchette and Wright (1992): inner-ramp association (lithofacies A1, $A 2, A 3$ ); mid-ramp (lithofacies B1, B2, Md1, Md2, Md3, Md4 and S); and distal ramp (lithofacies B3, Md5 and $S$ ).

\subsection{Clastic facies associations}

\subsubsection{Slope aprons}

Unsorted to poorly sorted calcareous breccias (facies G, Table 1) form metre- to decametre-thick, poorly-bedded packages. Calcareous lithoclasts comprise a wide spectrum of carbonate rocks derived from

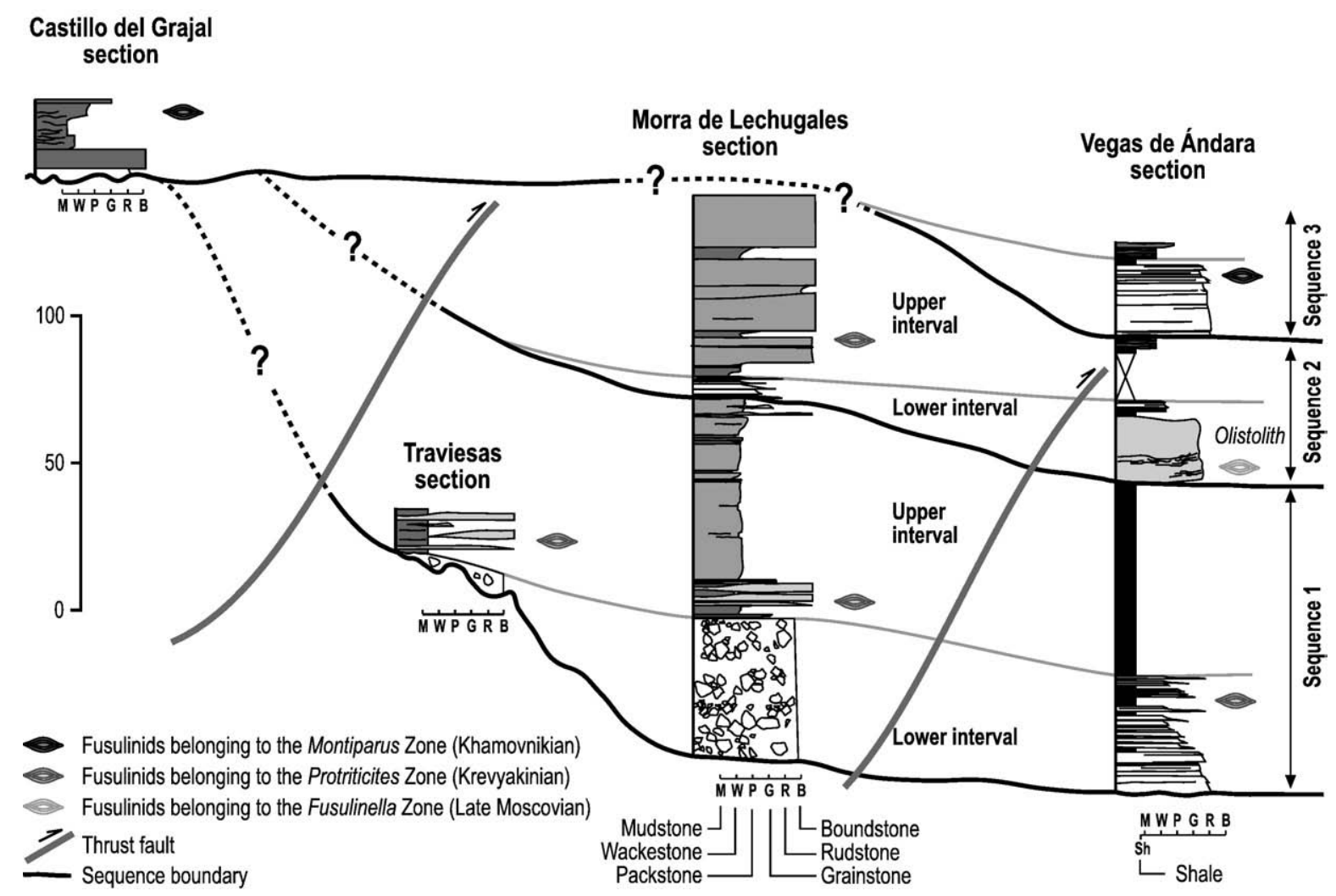

Fig. 4. Stratigraphy of Las Llacerias Formation in studied area. 


\section{MORRA DE LECHUGALES SECTION}

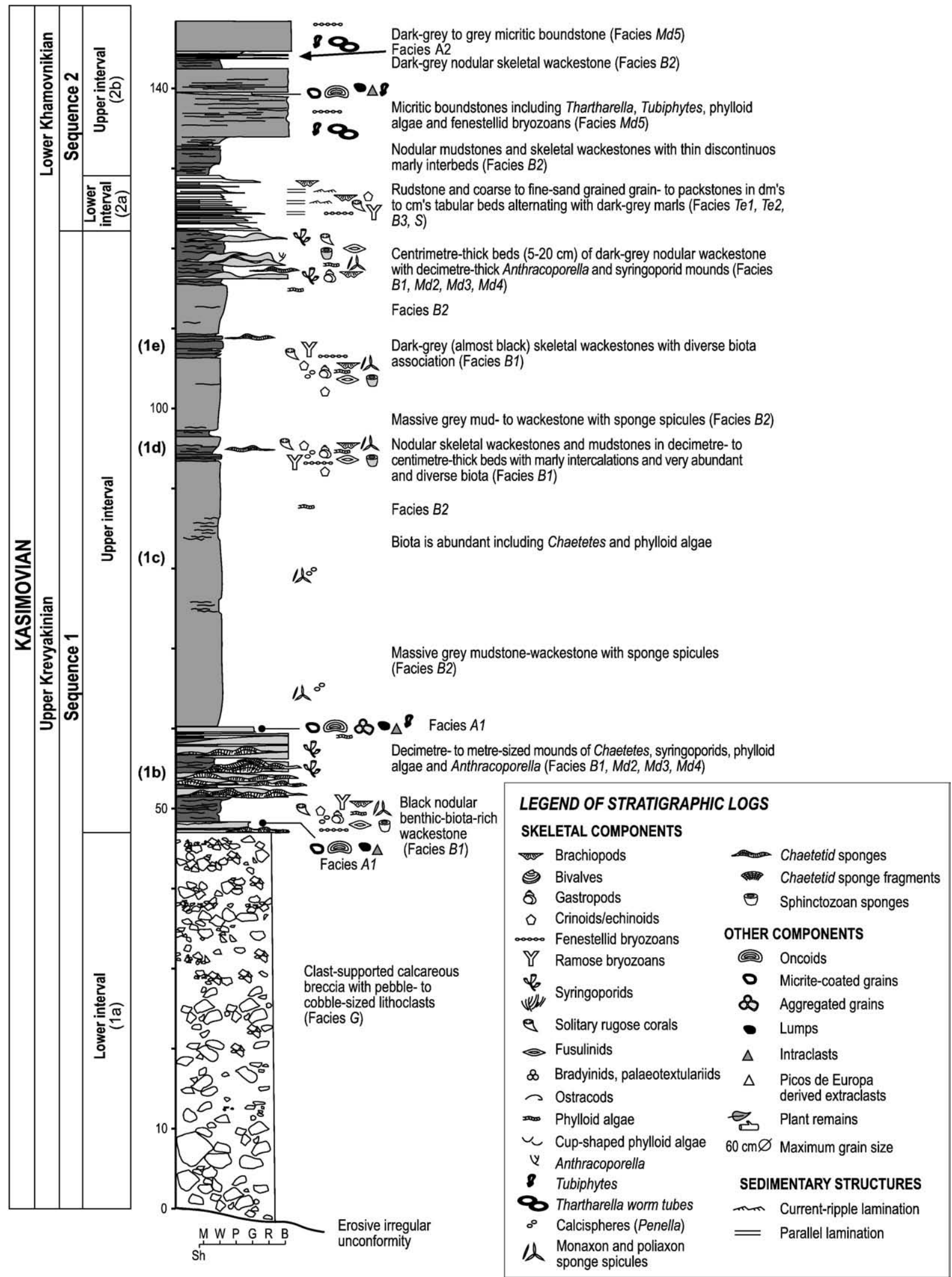

Fig. 5. Stratigraphic section of Las Llacerias Formation at Morra de Lechugales peak showing bedding packages recognizable in outcrop (1a-2b).

the underlying Picos de Europa Formation, the Las Llacerias Formation, scattered skeletal grains (Fig. 7A), and in places contain wellrounded quartzitic clasts (Fig. 7B). Locally, chaetetid and syringoporid colonies occur on top of these packages (Fig. 6). In a few localities, these coarse clastic deposits interfinger with black homogeneous shales (facies S). 


\section{TRAVIESAS SECTION}

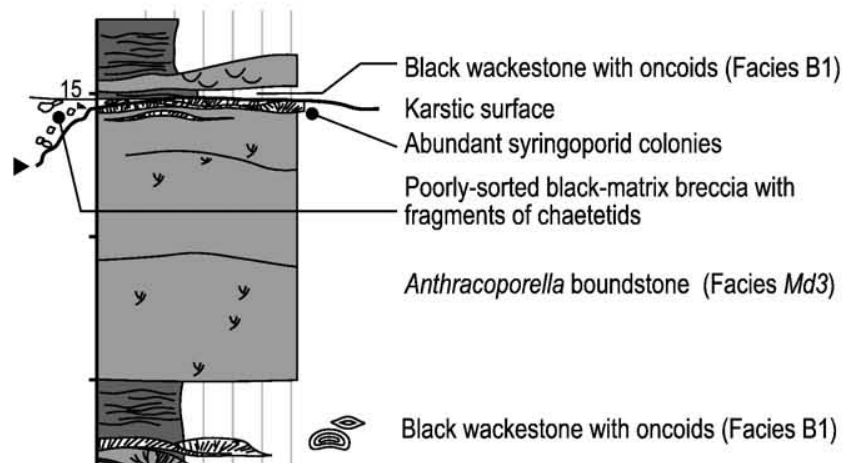

\begin{tabular}{l}
$\frac{c}{0}$ \\
0 \\
$\frac{0}{0}$ \\
\hline 0 \\
0 \\
0 \\
0 \\
0 \\
0
\end{tabular}

Chaetetes growing above breccia

Poorly-sorted black-matrix breccia with algal and Chaetetes fragments

In situ Chaetetes colonies and minor algalbafflestone patches (Facies Md1)

Black wackestone with oncoids (Facies B1)

Facies Md1

Phylloid algal bafflestone (Facies Md4)

$\circ \stackrel{8}{12}$ Black skeletal wackestones (Facies B1) \%०

\section{MORRA DE LECHUGALES SECTION}

$\triangle$ Skeletal grainstone with small-sized lithoclasts

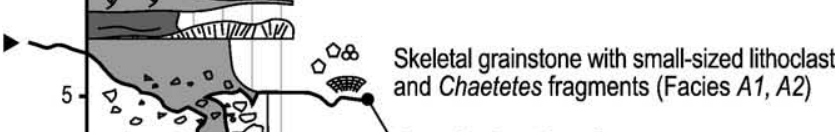

Irregular karstic surface

Poorly-sorted breccia with Chaetetes fragments and skeletal matrix (Facies G)

Black skeletal wackestone (Facies B1)

Phylloid-algal and Anthracoporella bafflestone

* (Facies Md3, Md4) (Facies Md1)

Clast-supported breccia containing lithoclasts of phylloid-algal and Anthracoporella bafflestones, skeletal pack- to grainstone, and Chaetetes fragments (Facies G).

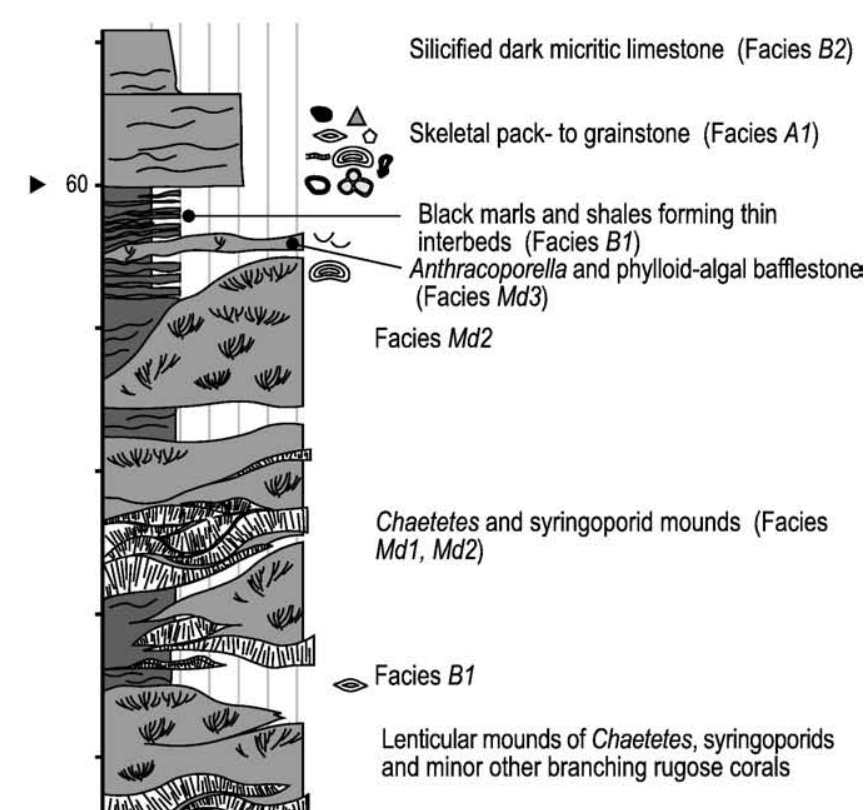

Facies Md1

Facies B1

Facies Md1

Facies B1

Facies Md2

Facies Md1

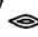

Very abundant echinoderm debris

Black skeletal wackestone including algal fragments, foraminifers, corals, echinoderms siliceous sponge spicules, ostracods, brachiopods and gastropods (Facies B1)

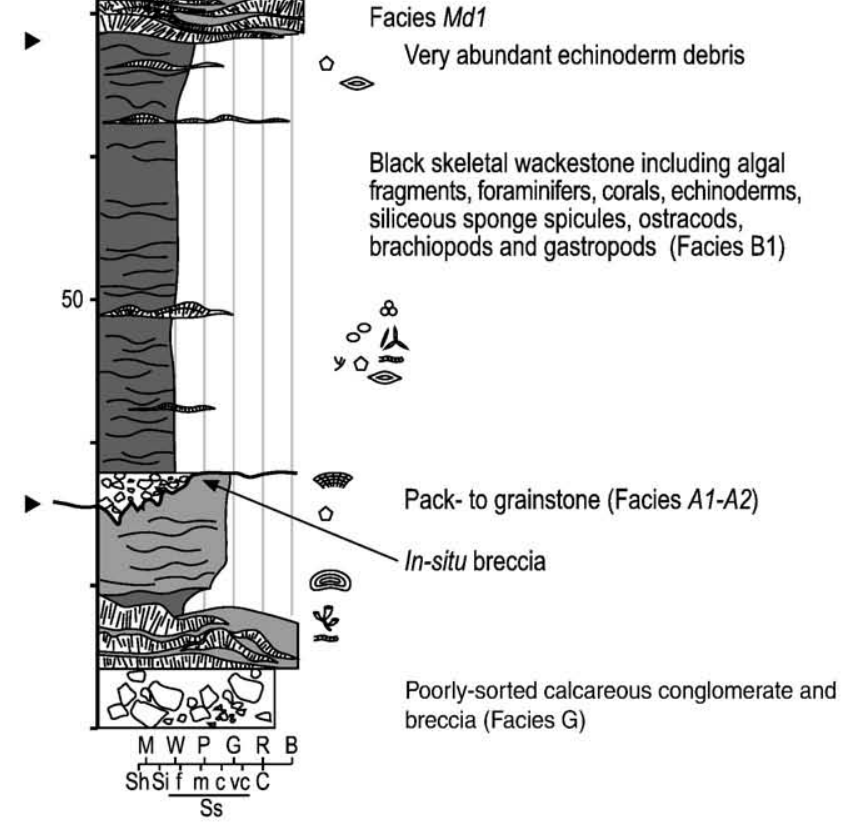

- Maximum regressive surfaces

$M W P G R B$

ShSif mcvc C

Fig. 6. Detailed stratigraphic sections of stratigraphic package $1 \mathrm{~b}$ of sequence 1 at Las Traviesas and Morra de Lechugales sections. See Fig. $2 \mathrm{~B}$ for location. 
Table 1

Lithofacies of the Las Llacerias Formation in the Andara area.

\begin{tabular}{|c|c|c|c|}
\hline Lithofacies, lithology, texture & $\begin{array}{l}\text { Geometry, bed thickness, sedimentary } \\
\text { structures }\end{array}$ & Composition: non-skeletal and skeletal grains, matrix & Depositional processes and environment \\
\hline $\begin{array}{l}\text { : Matrix-free } \\
\text { clast-supported } \\
\text { breccia and } \\
\text { conglomerate }\end{array}$ & $\begin{array}{l}\text { dm- to m-thick massive beds. Locally } \\
\text { normal grading }\end{array}$ & $\begin{array}{l}\text { Pebble- to boulder-sized angular to poorly rounded } \\
\text { carbonate lithoclasts, and scarce quartzitic pebbles and } \\
\text { boulders. Skeletal grains in variable amounts }\end{array}$ & $\begin{array}{l}\text { Hyperconcentrated to concentrated } \\
\text { density flows }\end{array}$ \\
\hline $\begin{array}{l}\text { Te1: Rudstone } \\
\text { grading into } \\
\text { grainstone to } \\
\text { packstone }\end{array}$ & $\begin{array}{l}\mathrm{cm} \text { - to } \mathrm{dm} \text {-thick tabular beds, erosive } \\
\text { bases and sharp to gradational tops. } \\
\text { Normal grading, locally parallel and cross } \\
\text { lamination }\end{array}$ & $\begin{array}{l}\text { A: intraclasts and extraclasts. C-S: crinoids, echinoids, } \\
\text { brachiopod and mollusk shell fragments, algal thalli, } \\
\text { bryozoans, foraminifers, Tubiphytes. R: calcareous } \\
\text { sponges, coral debris, trilobites, calcispheres, ostracodes, } \\
\text { and sponge spicules, detrital quartz grains. }\end{array}$ & Concentrated density flows \\
\hline $\begin{array}{l}\text { Te2: Grainstone } \\
\text { and packstone }\end{array}$ & $\begin{array}{l}\mathrm{cm} \text {-thick tabular beds, sharp erosive } \\
\text { bases and gradational tops. Normal } \\
\text { grading, parallel lamination at bed tops }\end{array}$ & $\begin{array}{l}\text { Same as in Te1, but skeletal debris more abundant. } \\
\text { Calcispheres, monaxon sponge spicules, ostracodes and } \\
\text { small foraminifers are abundant in bed tops }\end{array}$ & $\begin{array}{l}\text { Low concentration turbulent gravity } \\
\text { flows (distal tempestites) }\end{array}$ \\
\hline $\begin{array}{l}\text { S: Black to dark- } \\
\text { grey shale and marl }\end{array}$ & & $\begin{array}{l}\text { S-R: Scattered brachiopods, crinoids, Cyataxonia-type } \\
\text { corals, sphinctozoan sponges }\end{array}$ & $\begin{array}{l}\text { Low-energy settings. Subphotic to } \\
\text { aphotic }\end{array}$ \\
\hline $\begin{array}{l}\text { A1: Grainstone and } \\
\text { minor packstone }\end{array}$ & $\begin{array}{l}\mathrm{dm} \text { - to } \mathrm{cm} \text {-thick tabular to undulating } \\
\text { beds. Massive or locally cross bedding } \\
\text { and parallel lamination. Large burrows }\end{array}$ & $\begin{array}{l}\text { A-VC: micritic coated and aggregate grains. C: crinoids, } \\
\text { echinoids, small-sized and larger foraminifers } \\
\text { [Bradyinidae, Palaeotextulariidae (mainly } \\
\text { Climacammina), staffellids, other fusulinoideans], } \\
\text { brachiopods, algal thalli (Anthracoporella, } \\
\text { Eugonophyllum). S: smaller foraminifers } \\
\text { (biseriamminids, tetrataxids, tubiforms; Calcivertellinae, } \\
\text { Calcitornellinae Apterrinellinae), Tubiphytes bryozoans, } \\
\text { mollusks, calcispheres (Penella), polyaxon sponge } \\
\text { spicules. R: ostracodes, sponge fragments, trilobites. R- } \\
\text { VR: detrital quartz grains }\end{array}$ & $\begin{array}{l}\text { Shallow water, highly to moderately } \\
\text { agitated. Above effective fair-weather } \\
\text { wave base. Subtidal shoals and beaches. } \\
\text { Euphotic zone }\end{array}$ \\
\hline $\begin{array}{l}\text { A2: Packstone to } \\
\text { grainstone, minor } \\
\text { wackestone }\end{array}$ & Same as A1 & $\begin{array}{l}\text { VC-C: small-sized and larger foraminifers [Bradyinidae, } \\
\text { Palaeotextulariidae (mainly Climacammina), staffellids, } \\
\text { other fusulinoideans, biseriamminids, tetrataxids, } \\
\text { tubiforms; Calcivertellinae, Calcitornellinae } \\
\text { Apterrinellinae]. C: micrite-coated and aggregate grains, } \\
\text { phylloid algae, brachiopods, crinoids, echinoids, } \\
\text { calcispheres, bryozoans. S: polyaxon sponge spicules, } \\
\text { Tubiphytes. R-VR: detrital quartz grains. }\end{array}$ & $\begin{array}{l}\text { Shallow water, less agitated. Above or } \\
\text { close to effective fair-weather wave base. } \\
\text { Euphotic zone }\end{array}$ \\
\hline $\begin{array}{l}\text { A3: Rudstone and } \\
\text { floatstone }\end{array}$ & $\begin{array}{l}\mathrm{dm} \text { - to } \mathrm{cm} \text {-thick tabular to lenticular } \\
\text { beds, erosive bases and sharp to } \\
\text { gradational tops }\end{array}$ & $\begin{array}{l}\text { A-VC: Osagia oncoids. Skeletal packstone matrix similar } \\
\text { to lithofacies A2 }\end{array}$ & Same as A2 \\
\hline $\begin{array}{l}\text { B1: Wackestone and } \\
\text { packstone }\end{array}$ & $\begin{array}{l}\mathrm{cm} \text { to } \mathrm{dm} \text { pseudo-nodular to undulating } \\
\text { beds with discontinuous marly } \\
\text { interbeds. Intense bioturbation }\end{array}$ & $\begin{array}{l}\text { C: calcareous algae (Eugonophyllum, Anthracoporella, } \\
\text { Archaelithophyllum), foraminifers [Bradyinidae, } \\
\text { Palaeotextulariidae (mainly Climacammina), staffellids, } \\
\text { other fusulinoideans, biseriamminids, tetrataxids, } \\
\text { tubiforms; Calcivertellinae, Calcitornellinae } \\
\text { Apterrinellinae], brachiopods, bryozoans, crinoids, } \\
\text { echinoids, mollusks. S: sponge spicules, calcispheres, } \\
\text { chaetetids, sphinctozoans and lithistid sponges, tabulate } \\
\text { syringoporid corals, solitary geoyerophyllid rugose } \\
\text { corals, ostracodes, trilobites, Tubiphytes, Osagia oncoids. } \\
\text { R-VR: quartz grains }\end{array}$ & $\begin{array}{l}\text { Shallow subtidal, close to fair-weather } \\
\text { wave base. Euphotic to mesophotic zone. }\end{array}$ \\
\hline $\begin{array}{l}\text { B2: Skeletal } \\
\text { mudstone to } \\
\text { wackestone }\end{array}$ & $\begin{array}{l}\text { Undulating massive beds. Locally } \\
\text { nodular }\end{array}$ & $\begin{array}{l}\text { C: calcispheres and polyaxon sponge spicules. S: } \\
\text { foraminifers (biseriamminids, tetrataxids, } \\
\text { fusulinoideans, tubiforms; Calcivertellinae, } \\
\text { Calcitornellinae Apterrinellinae), calcareous algae } \\
\text { (phylloids, dasycladaceans), brachiopods, mollusks, } \\
\text { bryozoans, crinoids, echinoids, calcareous sponges } \\
\text { (inozoan, sphinctozoan; Discosiphonella, } \\
\text { Amblysiphonella, Sollasia), Cyataxonia-type corals. R: } \\
\text { Tubiphytes and ostracodes. R-VR: detrital quartz grains }\end{array}$ & $\begin{array}{l}\text { Subtidal, below fair-weather wave base. } \\
\text { Mesophotic to oligophotic zone }\end{array}$ \\
\hline B3: Marly mudstone & $\begin{array}{l}\mathrm{cm} \text { - to dm-thick, pseudo-nodular to } \\
\text { almost tabular beds. Massive to thinly } \\
\text { laminated }\end{array}$ & $\begin{array}{l}\text { C: Monaxon sponge spicules. S-R: crinoids and } \\
\text { echinoids, thin-shelled brachiopods, bryozoans, solitary } \\
\text { rugose corals, small foraminifers, calcispheres, } \\
\text { ostracodes, silt-sized detrital quartz grains }\end{array}$ & $\begin{array}{l}\text { Quiet, deep subtidal. Mostly below storm } \\
\text { wave base. Aphotic and locally } \\
\text { oligophotic zone }\end{array}$ \\
\hline $\begin{array}{l}\text { Md1: Chaetetid } \\
\text { sponge Framestone }\end{array}$ & dm- to m-thick lenticular beds & $\begin{array}{l}\text { A: Laminar and domical chaetetid sponge colonies, C: } \\
\text { syringoporids, solitary and branching rugose corals. S-R: } \\
\text { Phylloids and dasycladaceans, encrusting foraminifers } \\
\text { and Thartharella. Matrix: clotted and peloidal micrite }\end{array}$ & $\begin{array}{l}\text { Shallow subtidal, below effective wave } \\
\text { base. Euphotic zone. Chaetetid reef- } \\
\text { mounds }\end{array}$ \\
\hline $\begin{array}{l}\text { Md2: Syringoporid } \\
\text { coral branchstone to bafflestone }\end{array}$ & dm- to m-thick lenticular beds & $\begin{array}{l}\text { A: Syringoporid corals (Neomultithecopora).S-R: laminar } \\
\text { chaetetid sponges, solitary rugose corals, encrusting } \\
\text { foraminifers and Thartharella. Matrix: clotted-peloidal } \\
\text { micrite and homogeneous allomicrite }\end{array}$ & $\begin{array}{l}\text { Shallow subtidal, below effective fair- } \\
\text { weather wave base. Euphotic zone. Coral } \\
\text { reef-mounds }\end{array}$ \\
\hline $\begin{array}{l}\text { Md3: Anthracoporella } \\
\text { algal bafflestone }\end{array}$ & dm- to m-thick lenticular beds & $\begin{array}{l}\text { A: Anthracoporella. C-S: encrusting foraminifers, } \\
\text { Thartharella and calcified Girvanella filaments. S-R: } \\
\text { phylloids, ramose dasycladaceans, syringoporid corals } \\
\text { and chaetetid colonies. Matrix: clotted-peloidal micrite } \\
\text { and allomicrite }\end{array}$ & $\begin{array}{l}\text { Shallow subtidal, below fair-weather } \\
\text { wave base. Euphotic to mesophotic zone. } \\
\text { Anthracoporella mounds }\end{array}$ \\
\hline
\end{tabular}


Table 1 (continued)

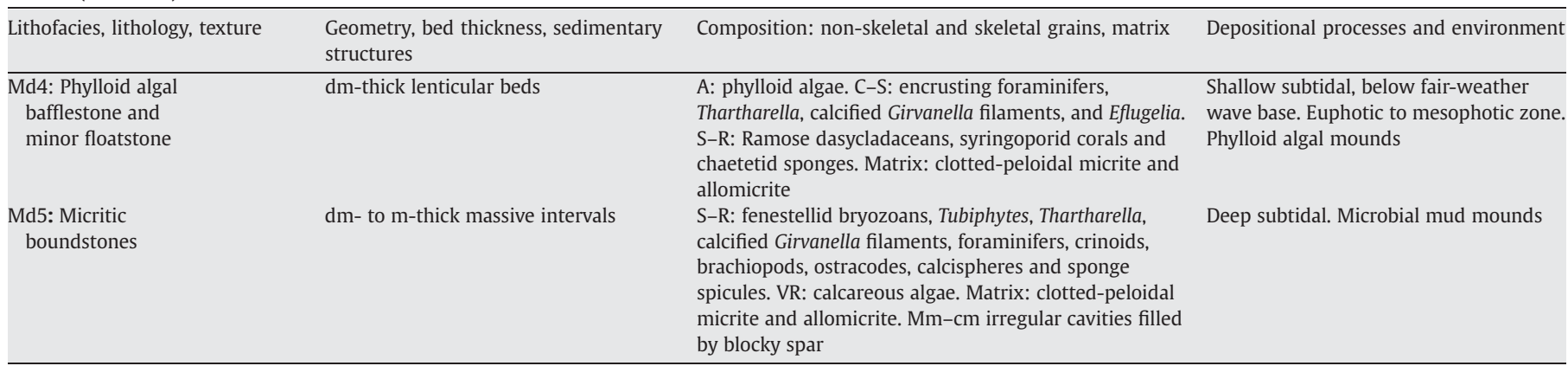

Relative percentages of skeletal and non-skeletal grains have been indicated according to Flügel (2004), as: VR = very rare $(<2 \%) ; \mathrm{R}=$ rare $(2-5 \%) ; \mathrm{S}=$ sparse $(5-10 \%) ; \mathrm{C}=$ common (10-30\%); VC = very common (30-50\%); $\mathrm{A}=$ abundant $(>50 \%)$.

5.1.1.1. Interpretation. The fabric and the lack of grading or imbrications of components in facies $\mathrm{G}$ suggest dense gravity-driven flows (granular flows sensu Narding et al., 1979; or hyperconcentrated density flows sensu Mulder and Alexander, 2001). The accumulation of these deposits occurred most likely close to the source area, as clastic aprons formed in steep shallow to deep coastal settings, comparable to debris cones reported by Postma (1990). These coarse clastic deposits bordered shallow-water to emergent areas.

\subsubsection{Mid- to outer-ramp tempestite deposits}

This association consists of metre- to decametre-thick packages of detrital carbonates (facies Te1 and Te2) alternating with dark nodular
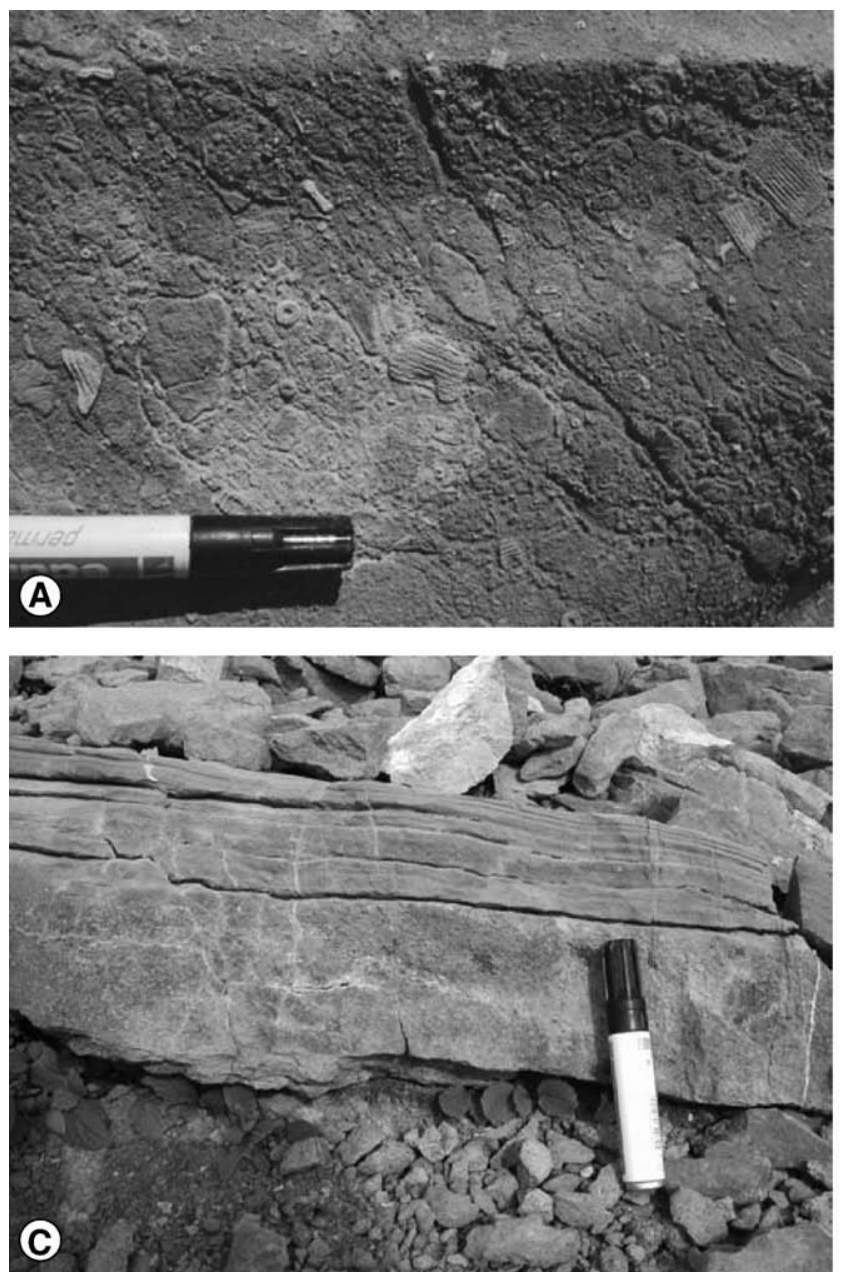

marls, lenses of marly limestones (facies B3) and, locally, dark-grey shales (facies S). Detrital carbonates form centimetre- to decimetrethick tabular beds (Fig. 7C) that can display a lower massive to normal graded layer of fine gravel-sized rudstones grading vertically into sand-grained packstones to grainstones. They contain abundant skeletal grains, rip-up mudstone clasts, extraclasts derived from the Picos de Europa Formation, intraclasts derived from the Las Llacerias Formation and detrital quartz grains (Fig. 7D). The bed tops usually are formed by fine sand- to silt-grained spiculitic packstones with traction-current structures (parallel and ripple lamination, Fig. 7C).

The interbedded marls, marly shales (facies S) and marly mudstones to wackestones (facies B3) contain small brachiopods, small rugose
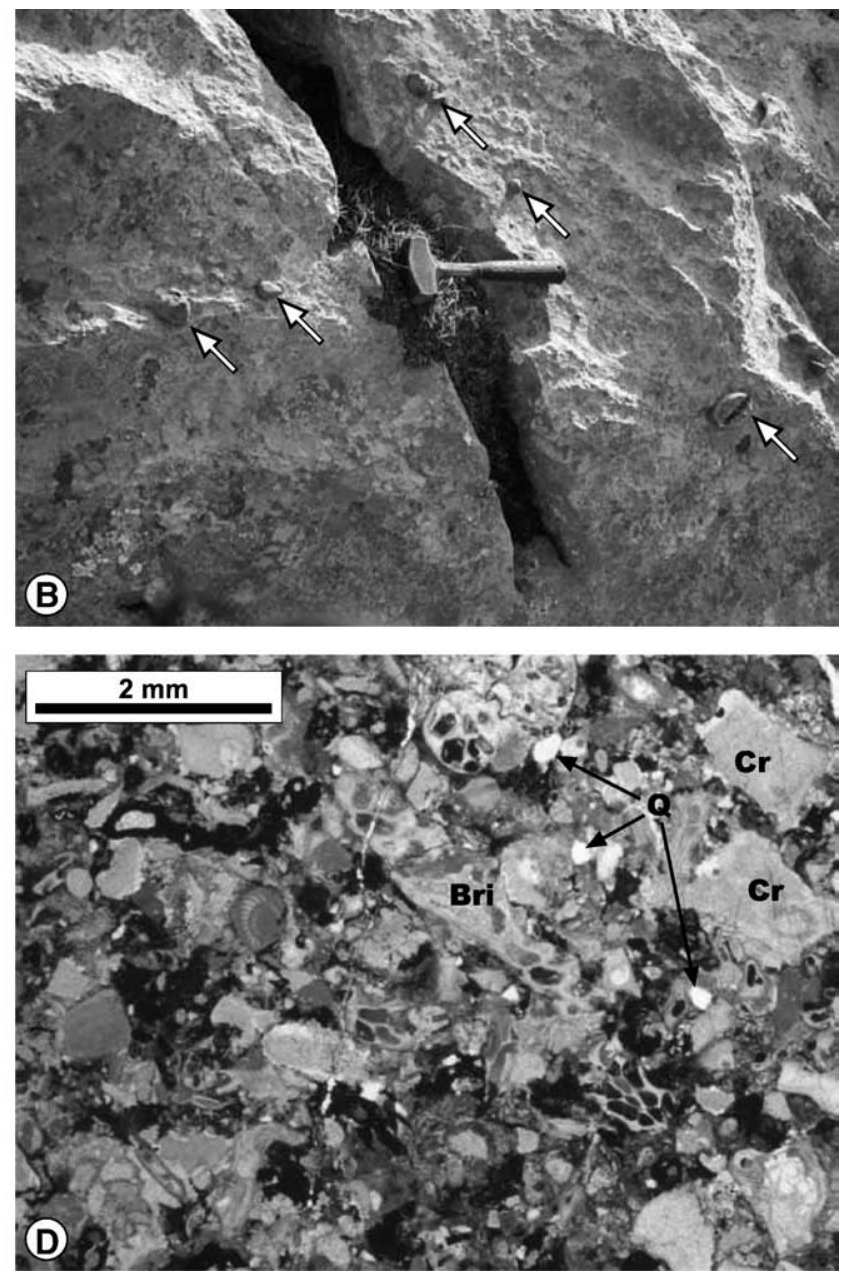

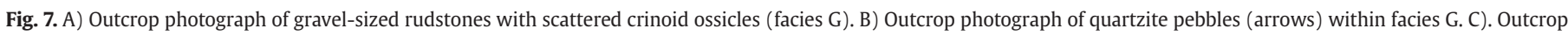

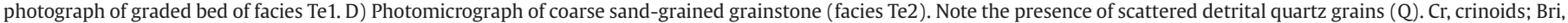
bryozoans. 
solitary corals, bryozoans, crinoids, gastropods, some trilobites and abundant monaxon sponge spicules and are intensely bioturbated.

5.1.2.1. Interpretation. The graded beds of detrital carbonates (facies Te1 and Te2) show features commonly reported from tempestite deposits accumulated in subtidal environments (Aigner, 1985; Handford, 1986; Wright, 1986) and in carbonate turbidites (Enos and Moore, 1983; Herbig and Bender, 1992; Herbig and Mamet, 1994). They are the result of sediment-load deposition by offshore-directed currents transporting the carbonate material eroded or reworked from shallower areas.

The intercalated facies B3 and S record the background sedimentation of lime-mud in low-energy subtidal environments with significant terrigenous input that caused frequently turbid waters and hampered the establishment of a more diverse marine calcareous biota. The small nondissepimented solitary corals (mostly Cyathaxonia sp.) also point to a deep-water realm below normal wave base (Somerville and Rodríguez, 2007). The depositional setting thus corresponds to a quiet environment typical for mid- to outer-ramps (Burchette and Wright, 1992).

\subsection{Autochthonous carbonate facies associations}

\subsubsection{Inner-ramp}

The inner-ramp deposits represent only a small portion of the very thick Las Llacerias Formation and occur mostly within the upper intervals of the sequences. They comprise decimetre- to metre-thick packages constituted by tabular to undulating beds of lithofacies A1, A2 and A3 (Table 1 ) that internally are massive or show cross bedding and parallel lamination. Skeletal grains include diverse foraminifers (Climmacammina, Deckerella, Staffella, bradyinids among others, and very abundant "tubiforms"), algal thalli, Tubiphytes (correctly Shamovella; Riding, 1993), echinoderms, brachiopods, mollusks, bryozoans, sponge fragments, calcispheres and polyaxon sponge spicules. Superficial micritization, microboring and micritic encrustation of skeletal grains forming both destructive and constructive micritic envelopes are very common and locally pervasive (Fig. 8). As such, cortoids (following terminology of Flügel, 1982; carbonate grains that include bioclasts, peloids, ooids or lithoclasts whose periphery exhibits a circumgranular non-laminated micritic rim), aggregate grains (mostly algal lumps) (Fig. 8A, B) and Osagia-type oncoids are commonly present and can be locally the main grain component. Oncoids, $0.5-7 \mathrm{~cm}$ in diameter, are spherical to ellipsoidal in shape and show a concentric-laminated micritic cortex (Fig. 8D) with abundant calcified filaments of cyanobacteria (Girvanella and/or Ellesmerella), encrusting foraminifers and the problematic alga Claracrusta sp. Primary interparticular porosity lacks fibrous marine cements.

5.2.1.1. Interpretation. The grain-supported texture, the scarcity of muddy matrix and the occurrence of traction sedimentary structures point to high- to moderate-energy conditions, probably in areas located close to or above wave base. These conditions occur in winnowed platform-edge sands as well as in current-washed sand shoals of inner-
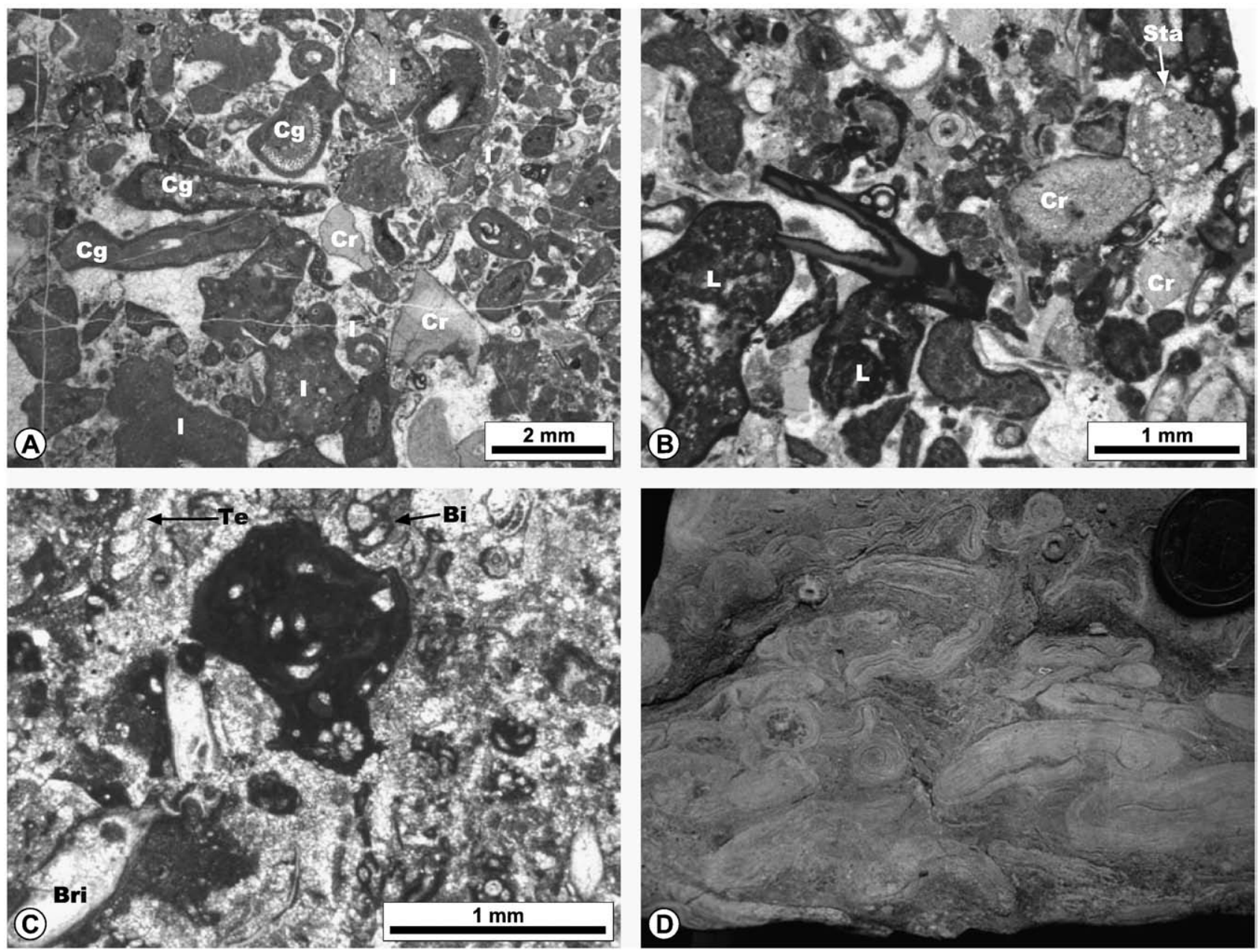

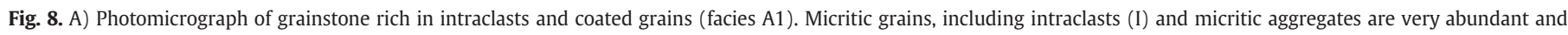

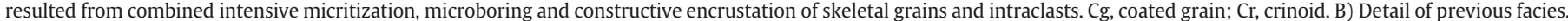

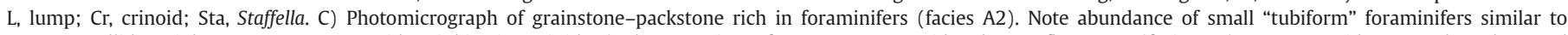

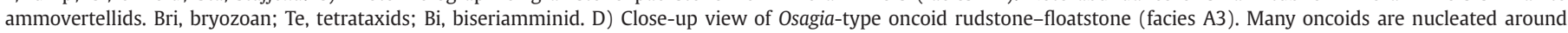
skeletal grains, commonly recognizable as thalli of phylloid algae. 5-cents Euro coin for scale. 
ramp settings (Tucker and Wright, 1990; Flügel, 2004). Coated grains (Leonard et al., 1981; Perry, 1998, 1999) and the abundance of large benthic foraminifers, such as Climmacammina, Deckerella, Staffella and bradyinids (cf. example of a Moscovian inner platform in Della Porta et al., 2006) had been usually considered as indicators of shallowmarine warm-water environments.
Facies A1 seems to record highly agitated environments while facies A2 probably corresponds to a less agitated and slightly deeper or protected realm. In the Early Permian of the Carnic Alps, Girvanella-foraminiferal oncolite beds, similar to those of our facies A3, occur in the Zweikofel Formation (formerly Upper Pseudoschwagerina Limestone), whose setting was interpreted
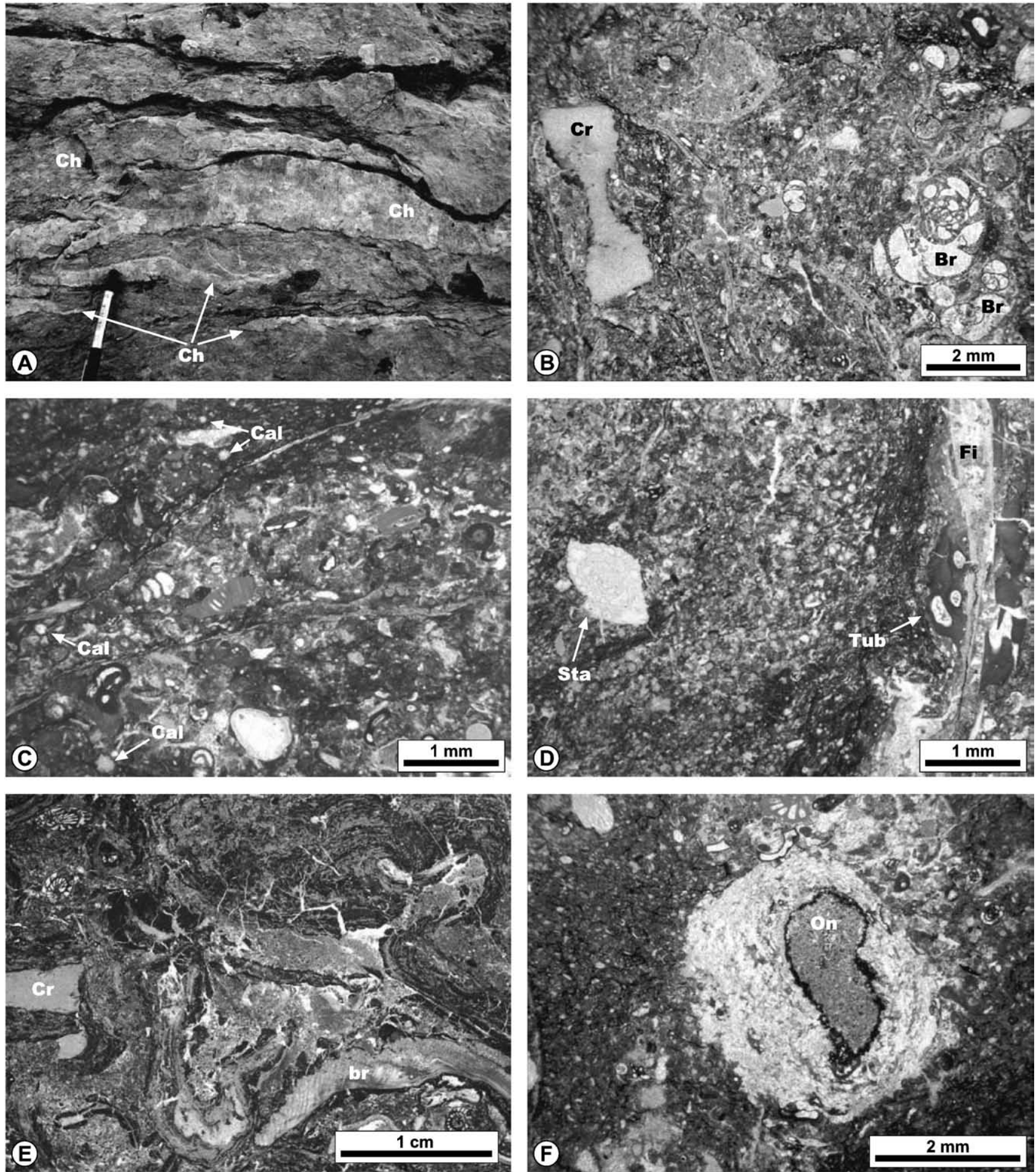

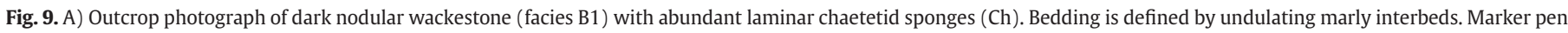

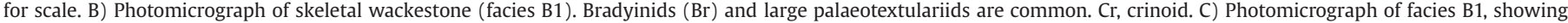

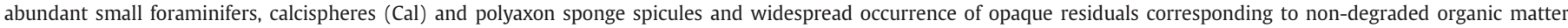

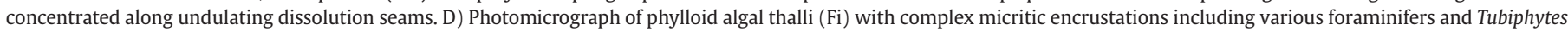

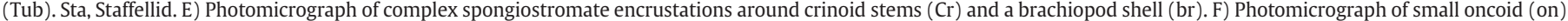
with cortex formed by thin calcified filaments of probable cyanobacteria. 
as a near-coast environment with high siliciclastic input (Flügel, 2004).

\subsubsection{Mid-ramp}

Black to dark-grey nodular marly wackestones and packstones, punctuated by interbeds of marls (facies B1 and B2) are the prevailing lithofacies in this facies association.

Facies B1 generally characterizes metre- to decametre-thick and thinly bedded packages (intervals $1 \mathrm{~b}, 1 \mathrm{~d}, 1 \mathrm{e}$ and on top of sequence 1 , as well as in sequences 2 and 3 ) with a high-diversity biotic association. In those packages numerous decimetre- to metre-thick buildups of chaetetids (facies Md1, only present in sequence 1), syringoporids (facies Md2), dasycladaceans (mainly Anthracoporella) and phylloid algae (facies Md3 and Md4, respectively) occur. B1 lithofacies are black nodular marly wackestones and packstones punctuated by interbeds of marls (Fig. 9A) and contain abundant algae, conspicuous swarms of Penella (Mamet and Villa, 2004), polyaxon sponge spicules and very rich heterozoan fauna including
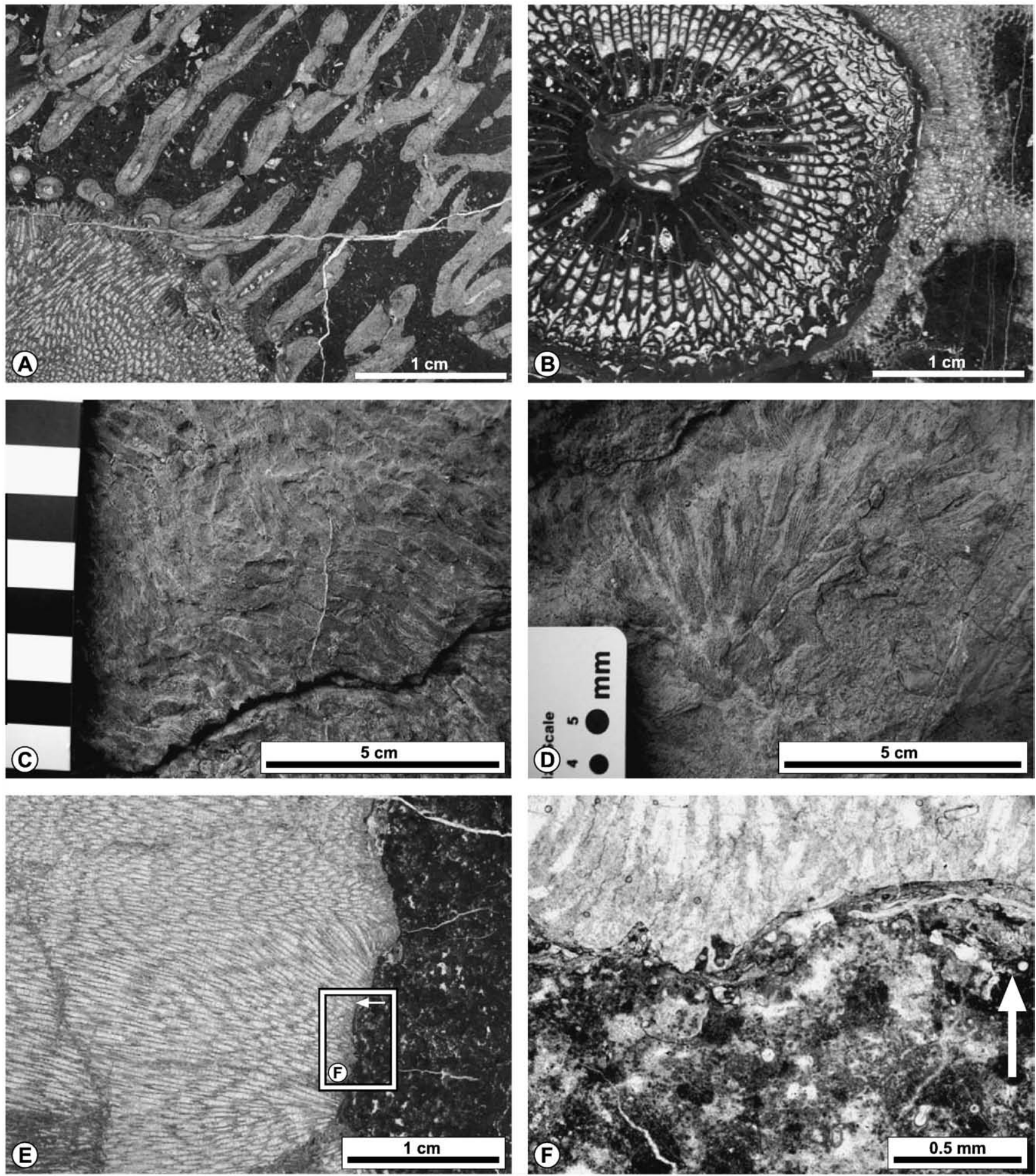

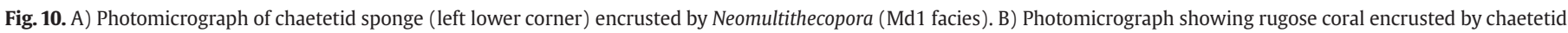

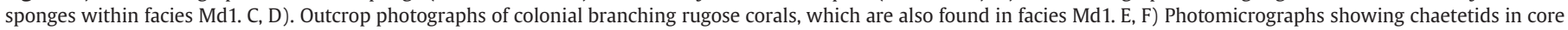
facies of a chaetetid-dominated buildup (Md1 facies). Peloidal to clotted micrite is also locally found (see detail in F). 
abundant foraminifers (Fig. 9B, C, D). Laminar chaetetids are characteristic (Fig. 9A), along with sphinctozoan and less abundant inozoan and lithistid sponges, tabulate syringoporids, solitary rugose geoyerophyllid corals and echinoderms. Skeletal grains usually show microborings, micritization and constructive micritic encrustations with abundant Girvanella, encrusting foraminifers and Claracrusta. Osagia-type oncoids are common (Fig. 9E, F) and appear locally concentrated in thin levels. Dark insoluble residues, organic matter and bitumen are enriched in undulating horsetail dissolution seams and fill dissolution and primary intraparticulate pores (Fig. 9C, D). Skeletal grains are locally silicified.

Chaetetid buildups (facies Md1) are composed of large densely growing colonies of chaetetid sponges with small-sized colonies of syringoporid corals (Neomultithecopora), colonial branching and
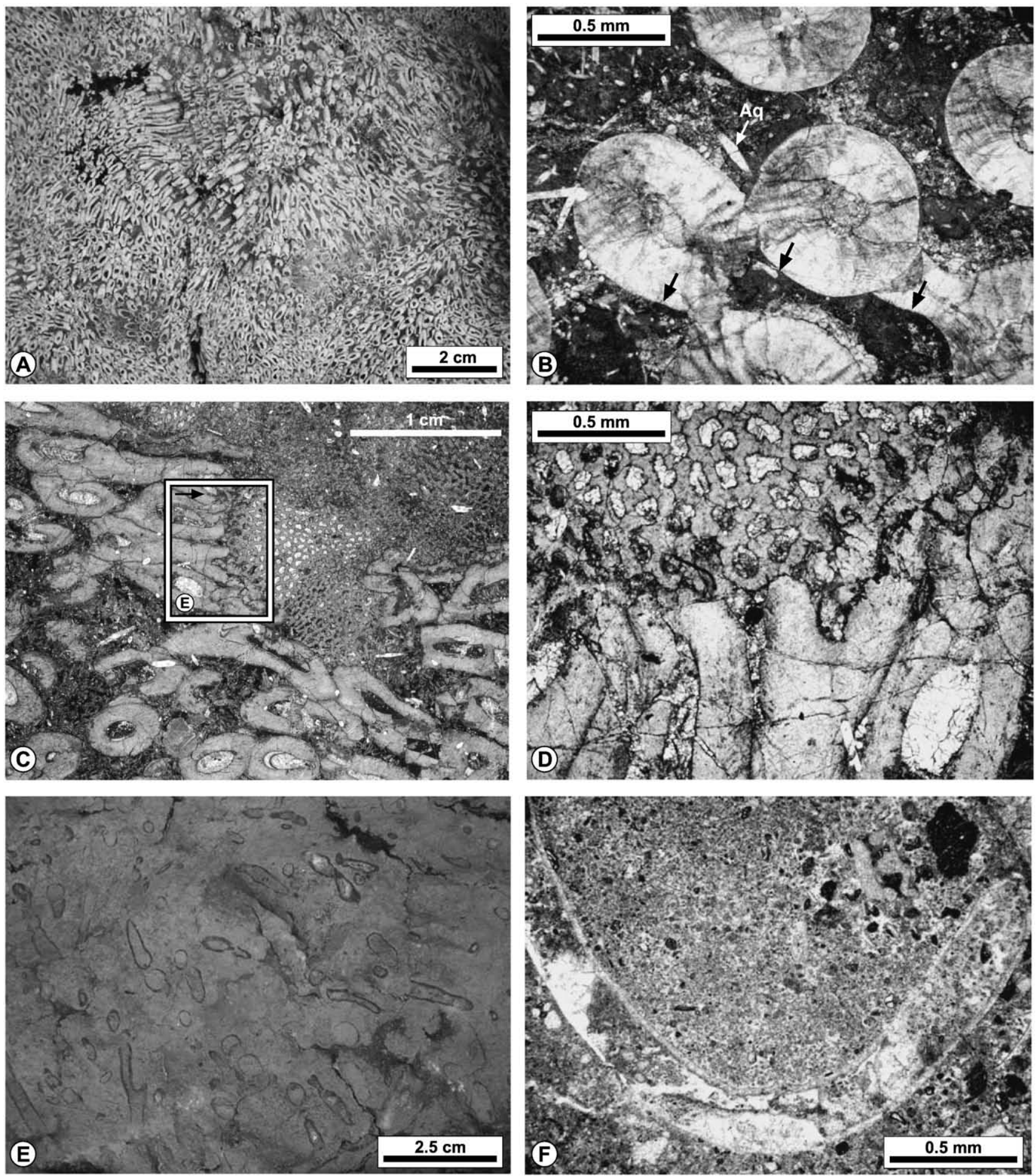

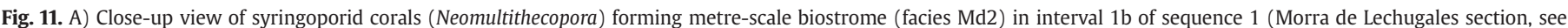

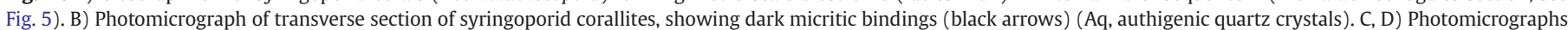

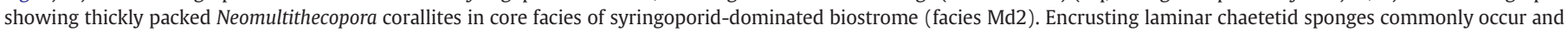

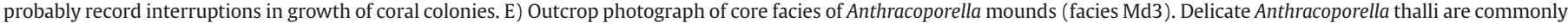
well preserved. F) Photomicrograph of cup-shaped phylloid algal thalli in bafflestone (facies Md3). 
solitary rugose corals that variously encrusted or grew intercalated with chaetetid sponges (Fig. 10A, B, C, D). Discontinuous patches of peloidal to clotted micrite (Fig. 10E, F) with turberitinids and micritic worm tubes, and patches of cup-shaped phylloid algal and Anthracoporella boundstones also form part of the mound core facies.

Densely packed colonies of Neomultithecopora form metre-scale buildups (facies Md2) with a convex-upward morphology and steep flanks (dipping up to $30^{\circ}$ ) (Fig. 11A, B). The tubular corallites of syringoporid corals are commonly connected by dark homogeneous micritic bindings (Fig. 11B) and the remaining space is filled by allomicrite, peloidal to clotted micrite and minor spar cement. Thin laminar chaetetid colonies (that locally form the substrate of the reefmounds) and branching and solitary rugose corals occur intercalated within syringoporid colonies (Fig. 11C, D).
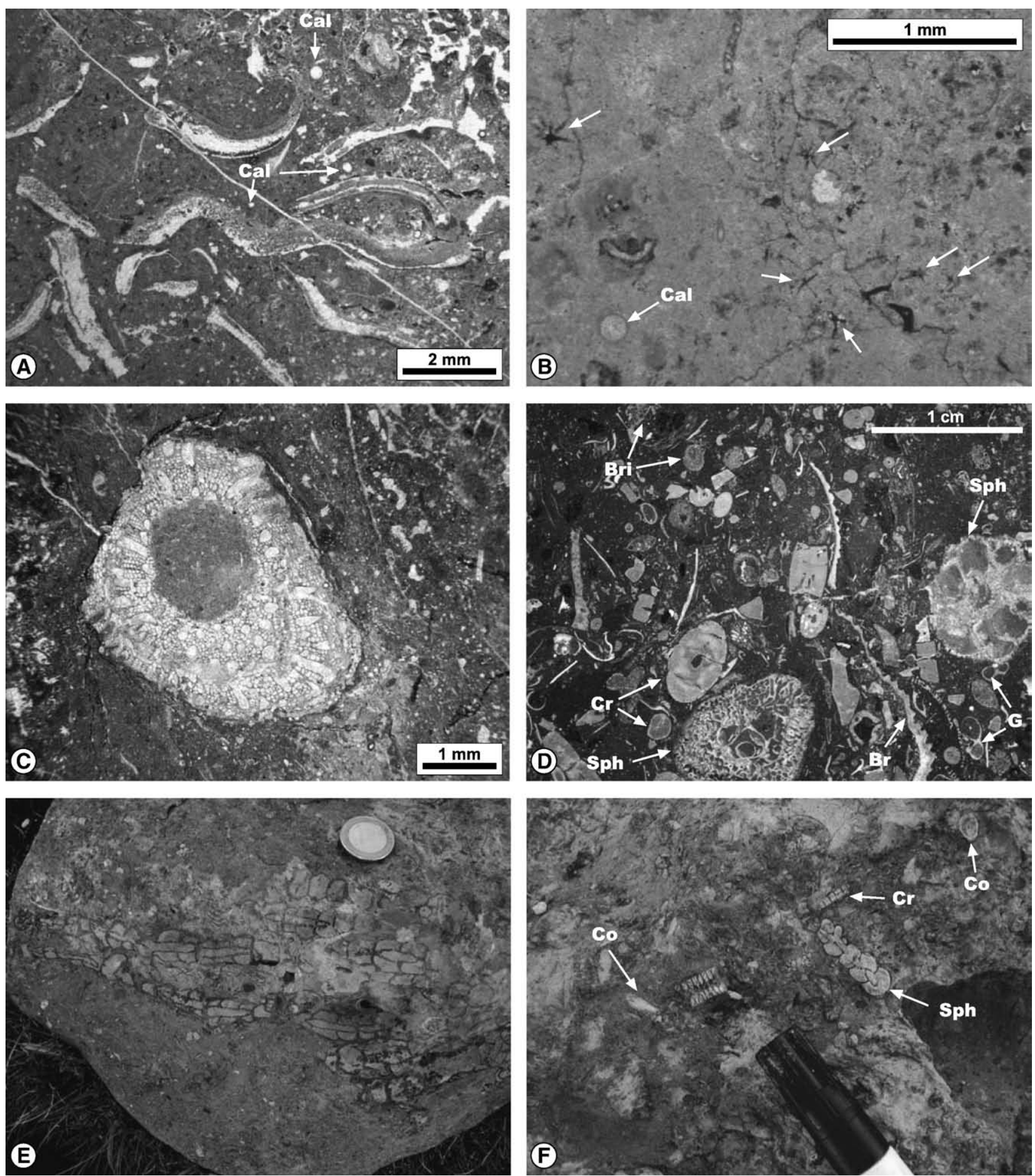

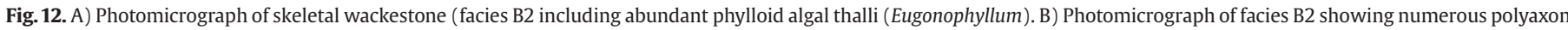
sponge spicule molds (arrows), calcispheres (Cal) and "tubiform" foraminifers. C) Photomicrograph of fistuliporid bryozoan in previous facies. D) Photomicrograph of a skeletal-rich wakestone interval containing abundant brachiopod shell fragments (Br), crinoids ( $\mathrm{Cr}$ ), ramose bryozoans (Bri), small gastropods (G) and sphinctozoan sponges (Sph). E) Large sphinctozoan sponge (Amblysiphonella) in facies B2. F) Close-up view of sphinctozoan sponges (Sph) with abundant crinoids (Cr), solitary Cyathaxonia rugose corals (Co), brachiopods and bryozoans (facies B2). 
Anthracoporella algal mounds (facies Md3) consist of successive stacking of massive algal boundstone lenses locally separated by discontinuous centimetre-thick marly bundles. In situ delicate branching colonies of Anthracoporella are ubiquitous (Fig. 11E) and usually are encrusted by foraminifers, calcified filaments of Girvanella, and the worm tube Thartharella. The marly bundles include phylloid algal thalli and usually display a crude lamination.

Phylloid algal mounds (facies Md4) consist of decimetre- to metrethick bodies generally with a short lateral extent (metres to decametres). The larger mounds are composed of stacked lenses of
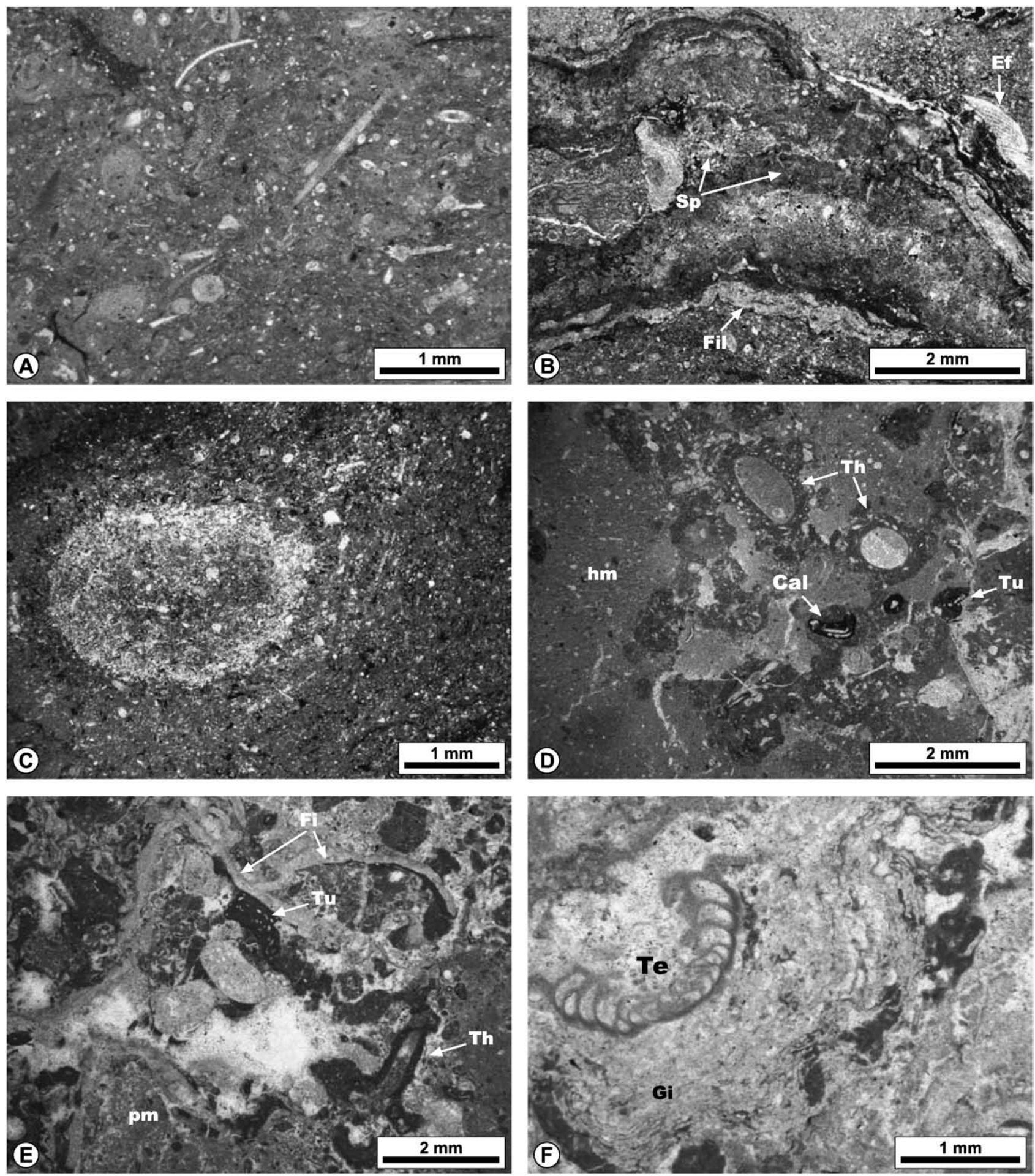

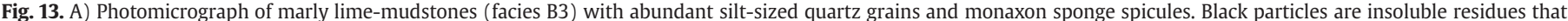

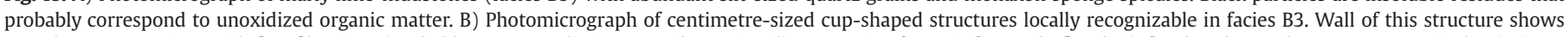

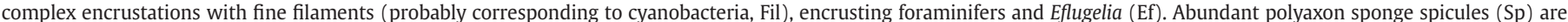

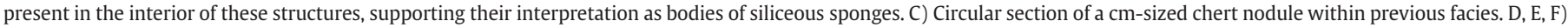

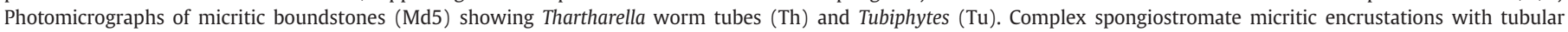

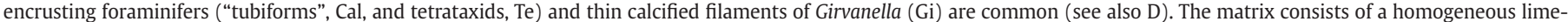
mud (hm) with fine skeletal debris or peloidal to clotted micrite (pm). Phylloid algae (Fi) locally occur within this facies (see also E). 
algal bafflestones punctuated by thin centimetre-thick discontinuous bundles of marly wackestones with abundant phylloid algal thalli and few laminar chaetetids and syringoporids. Phylloid algae include undulating and cup-shaped growth forms (probably corresponding to Eugonophyllum, Fig. 11F) and are encrusted by Girvanella, foraminifers and Eflugelia. Irregular sheltered cavities occluded by blocky spar are locally abundant, but fibrous and radiaxial-fibrous cements are absent in most cases.

Distinct from facies B1, facies B2 usually characterize metre- to decametre-thick packages with a massive appearance. Facies B2 consists of bioturbated mudstones to wackestones with abundant Penella and polyaxon sponge spicules that locally show marly interbeds. Skeletal grains include foraminifers (less abundant than in facies B1), algae, calcareous sponges, brachiopods, bryozoans, crinoids, echinoids, mollusks, Tubiphytes, corals and ostracodes (Fig. 12A, B, C). Algae in growth position (mainly Anthracoporella and phylloid algae) form centimetre to decimetre-thick, lens-shaped beds (Md3 and Md4). In some outcrops, marly nodular intervals bear numerous well-preserved sphinctozoan sponges (Discosiphonella, Amblyshiphonella and minor Sollasia), even forming small lenticular colonies with the sponge bodies preserved in life position, along with abundant brachiopods, large bryozoans (fenestellids, fistuliporids and other ramose forms), crinoid stems, the solitary rugose coral Cyathaxonia and gastropods (Fig. 12E, F). Silicification in skeletal grains and nodular chert has been observed.

5.2.2.1. Interpretation. Facies B1 and B2, with prevailing mudsupported texture lacking traction-current structures and preservation of delicate skeletons, indicate low-energy levels and point to a quiet, subtidal environment below fair-weather wave base. They are comparable to autochthonous carbonate sediments characterizing middle ramp depositional settings reported in other sites throughout the Phanerozoic (Wright 1986; Sami and Desrochers, 1992; Somerville and Strogen, 1992).

Stratal packages of facies B1 and the enclosed buildups probably record a shallow mid-ramp depositional setting under open-marine conditions. The widespread Anthracoporella and phylloid algal mounds (facies Md3 and Md4), commonly assigned to shallow, low-energy settings (Krainer, 1995; Samankassou, 1997, 1998, 1999; Soreghan and Giles, 1999; Samankassou, 2003), the abundance of chaetetid sponges, calcareous green algae and large benthic foraminifers (fusulinoideans, palaeotextulariids, bradyinids and Staffella) along with levels rich in Osagia-type oncoids agree with this interpretation. The various types of buildups in the study area are comparable to those reported throughout Late Palaeozoic deposits by previous authors.

Chaetetid-dominated buildups were reported from Pennsylvanian rocks in the North American Midcontinent, U.S.A. (West, 1988; Connolly et al., 1989; Suchy and West, 2001; Wahlman, 2002). They generally developed in very shallow-water palaeoenvironments or topographic highs including algal mounds (Connolly et al., 1989; Wahlman, 2002). The association of Chaetetes with tabulate syringoporid/auloporid and rugose corals forming buildups was reported by West and Clark (1984), Rodríguez and Ramírez (1987), Miller and West (1997), West (1988), Suchy and West (2001), among others.

Anthracoporella-dominated algal mounds, first described in the Carnic Alps by Krainer (1995) and Samankassou (1997, 1998, 1999, 2003), were rarely reported in coeval successions elsewhere. Overall, the studied Anthracoporella mounds show striking similarities to those described in the Carnic Alps.

Phylloid algae had a wide distribution during Pennsylvanian and Permian giving rise to the development of algal mounds in shallowwater environments of carbonate ramps and shelves (West, 1988; Wahlman, 2002). Samankassou and West (2002) and Forsythe (2003) documented cup-shaped phylloid algae that actively contributed to mound growth displaying similar features to those of some phylloid algal mounds described herein.
In the stratal packages dominated by facies B2 the minor occurrence of photozoans and the scarcity of certain biota and grains characterizing shallower environments (e.g. chaetetids, large benthic foraminifers, Osagia-type oncoids and coated grains) point to slightly deeper settings. The colonization of the sea floor locally by dasycladaceans (Anthracoporella) and phylloids (Eugonophyllum) forming small mounds (lithofacies $\mathrm{Md} 3$ and $\mathrm{Md} 4$, respectively), however, indicate a position within the photic zone.

\subsubsection{Outer-ramp}

The facies association consists of nodular marly mudstones and marls (B3), micritic boundstones (Md5) and minor marls and shales (S). Lithofacies B3 form centimetre- to decimetre-thick $(2-30 \mathrm{~cm})$ undulating-nodular to almost tabular beds (massive to thinly laminated) with scarce trace fossils. Monaxon, and minor polyaxon, siliceous sponge spicules (Fig. 13A) and a low diversity heterozoan fauna are characteristic. Locally, centimetre (up to $5 \mathrm{~cm}$ long) cupshaped structures made of dark homogeneous to lumpy micrite, including clusters of polyaxon sponge spicules and encrusted by Eflugelia and "calcivertellid" foraminifers are observed (Fig. 13B). Silicification affects skeletal grains, and small chert nodules are locally widespread in distinct layers (Fig. 13C).

The micritic boundstones (facies Md5) consist of clotted-peloidal micrite (automicrite, sensu Reitner and Neuweiler, 1995) with fenestrate bryozoans, the worm tube Thartharella, Tubiphytes, as well as inozoan and sphinctozoan sponges and rare algal thalli (Fig. 13D, E). These organisms commonly show complex spongiostromate micritic encrustations including calcified filaments and foraminifers (Fig. 13F). Homogeneous micrite (allomicrite), with scattered bioclasts, is volumetrically important.

5.2.3.1. Interpretation. The muddy matrix of rocks and the observed biotic associations almost lacking in situ algae point to deposition in a deep-water realm below the lower limit of the photic zone (or locally within the oligophotic zone), and most probably below storm wave base, i.e., the outer-ramp (Wilson, 1969; Faulkner, 1988; Burchette and Wright, 1992). Mud mounds (lithofacies Md5) typically occurred in distal parts of carbonate ramps (Lees and Miller, 1995; Jeffery and Stanton, 1996; Wendt et al., 2001). However, the occurrence of in situ algal thalli in the studied case indicates that these mounds apparently may also have developed in slightly shallower areas, close to the lower limit of the photic zone.

\section{Depositional model}

The depositional architecture described of the Las Llacerias Formation, consisting of unconformity-bounded sequences with a lower part of calcareous clastic deposits and an upper part of autochthonous carbonates, closely resembles the architecture of the younger Puentellés Formation (late Kasimovian-Gzhelian). The latter developed directly upon active tectonic growth structures linked with blind thrusts within a piggyback basin in the northern sector of the Picos de Europa Province (Merino-Tomé et al., 2007). Similarly, the Las Llacerias Formation could form small thrust-top carbonate platforms (according to the terminology of Bosence, 2005), nucleated on top of tectonic uplifts and passing southwards into a deep trough with clastic sedimentation. These uplifts would be linked to the incipient propagation of blind thrusts during mid Krevyakinian and Khamovnikian time (Fig. 14) (Merino-Tomé et al., 2009).

These early Kasimovian carbonate ramps developed synchronously with large deltaic systems, leading to accumulation of huge volumes of terrigenous sediments in the northern sector of Picos de Europa and to the W and S of the Picos de Europa Province originating from the adjacent and recently created mountainous areas of the Variscan Orogen (Figs. 1C and 14A). Terrigenous influx and, probably, periodic turbidity in the shallow waters affected the ramps developed 
(A)

(B)

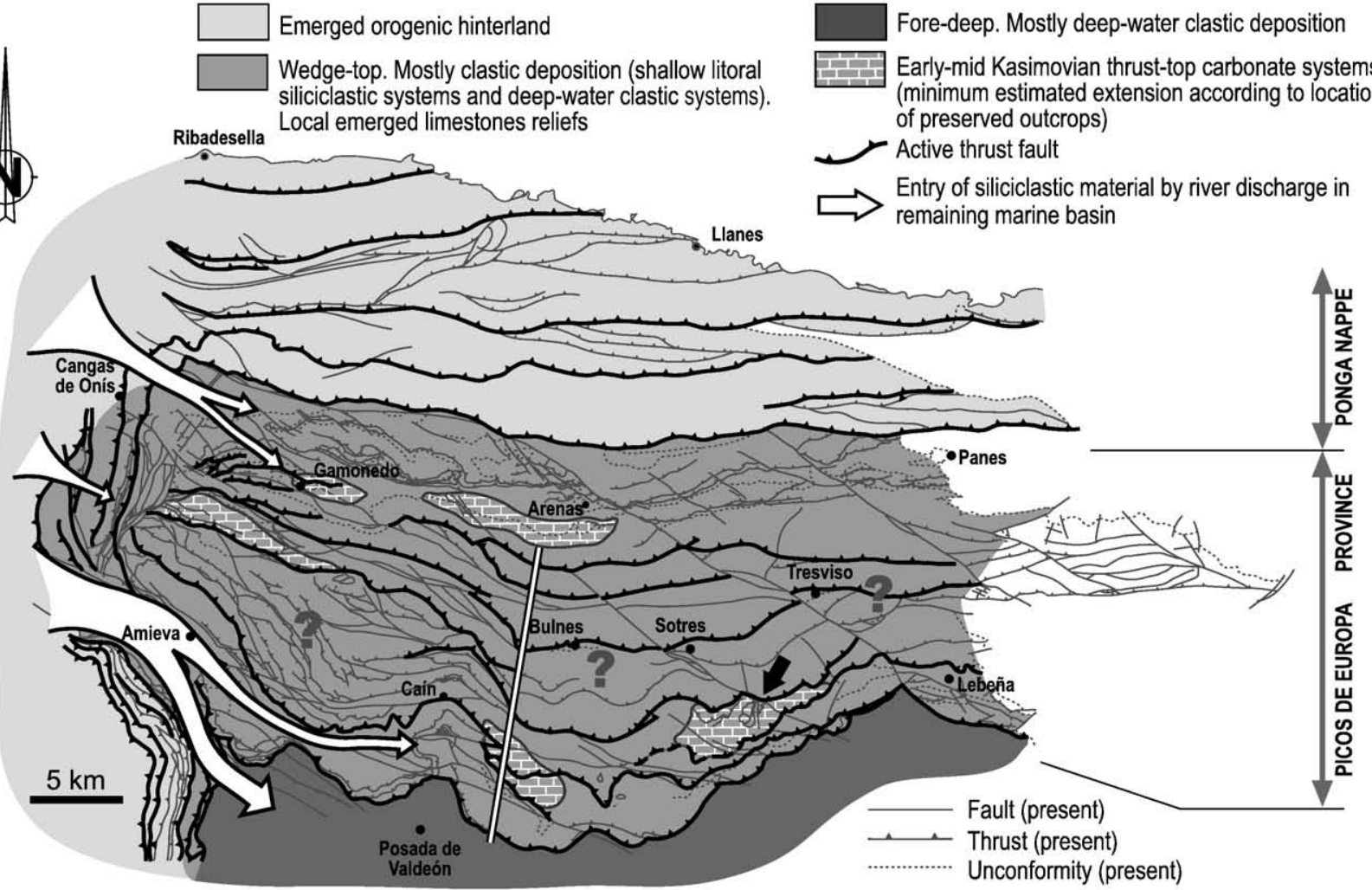

Deep-water troughs with clastic deposition. Shales were sourced from western-located deltaic and fan-deltaic systems while carbonate clastics were derived from adjacent tectonic
Growth anticlines (fault-propagation and detachment folds) where small-sized thrust-top carbonate ramps nucleated

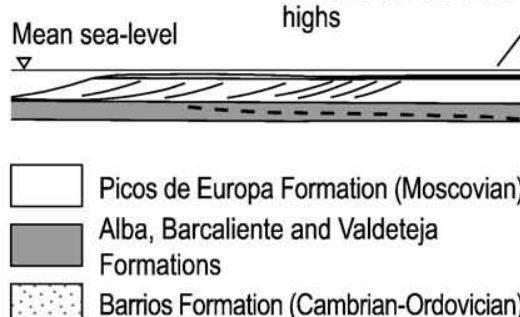

(C)

Emerged areas: subaerial exposure and karstification of the previous carbonate

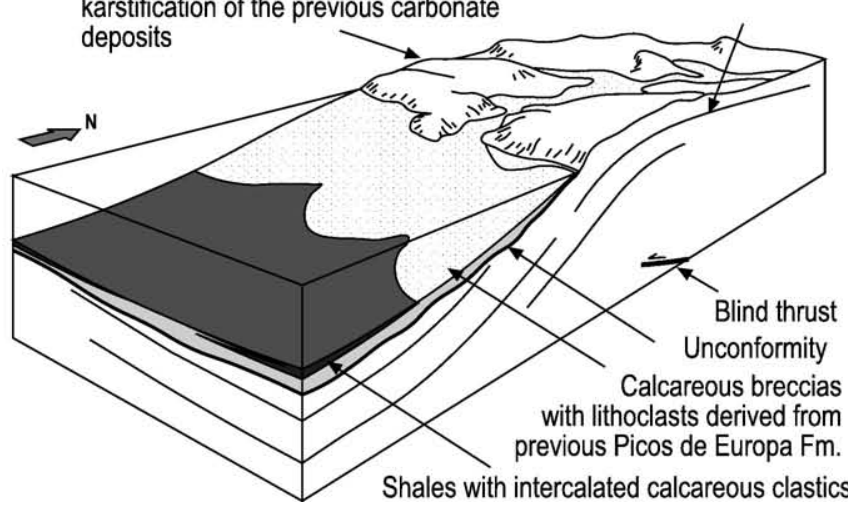

Picos de

Europa Fm.
Chaetetid and coral buildups

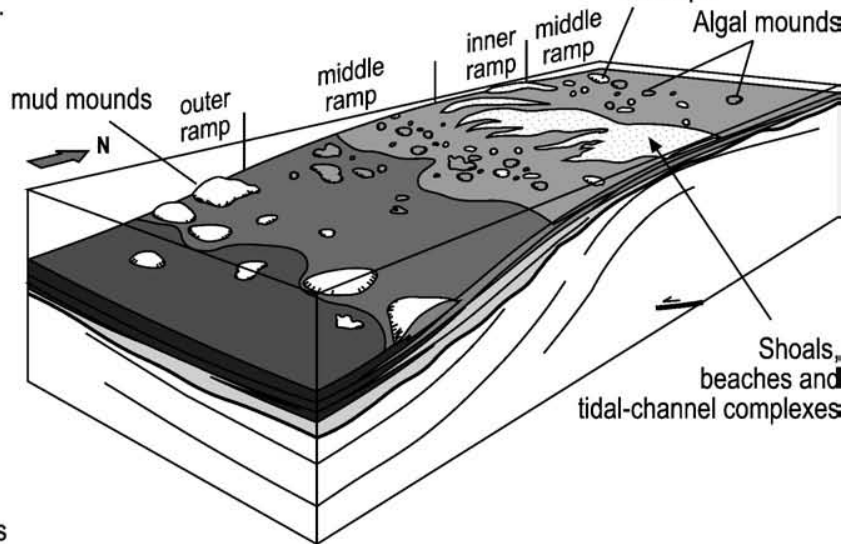

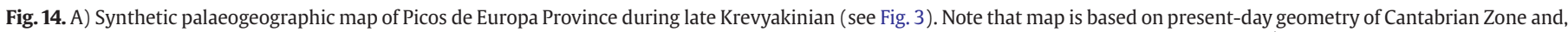

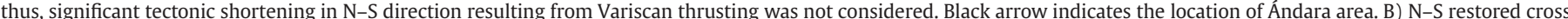

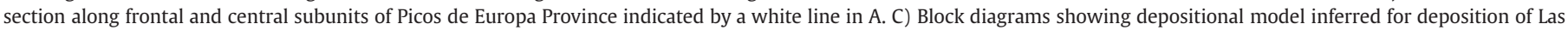
Llacerias Formation during the lower interval (left) and upper interval (right) of sequence 1 in Ándara area (black line labelled with C in B). 
in the Ándara area as recorded by the siliciclastic material present both in the clastic and autochthonous carbonates of the Las Llacerias sequences.

\subsection{Sedimentary environments}

Although a precise depositional profile of the carbonate ramp with palaeobathymetric data cannot be obtained due to the lack of undisturbed primary sedimentary sections and continuous exposures, qualitative estimations of depth distribution for the facies associations can be established based on sedimentological features and palaeoecological data. Specifically, in situ algae, microboring and superficial micritization processes represent reliable proxies to estimate lightpenetration depths.

Very shallow-water, high-energy environments with carbonate sand shoals and beaches were probably of limited spatial distribution. The scarcity of those deposits, but also of inferred storm-deposits (facies Te), can be explained either: 1) by the predominance of lowenergy conditions affecting the carbonate ramp with only sporadic high-energy storm events; or 2) because of the drowning to below wave base level of extensive areas of these carbonate systems. The latter would reduce the areal extension of shallow-water environments, which may have been the main source of the grains transported by the offshore-directed return currents.

Within low-energy and well-illuminated euphotic environments (euphotic zone sensu Pomar, 2001), a wide range of marine biota were organized in very complex benthic communities. Chaetetid sponges, tabulate (mainly syringoporid) and rugose corals, phylloid algae, and dasycladaceans thrived and built small, metre-scale buildups. Various algae including abundant phylloid udoteaceans, minor ramose dasycladaceans and, maybe poorly calcified algae, colonized extensive areas of the sea floor to form meadows. They may have provided suitable habitat for the very rich and diverse epiphytozoan communities (including the small "tubiform" foraminifers and others such as Tuberitinids, Tetrataxids, Palaeonubecularia, and organisms such as worms, Tubiphytes and cyanobacteria) characterizing the shallowwater environments of the studied ramp. On the other hand, algal meadows probably helped to stabilize the sediment (similarly to seagrasses) and promoted the development of constructive micrite envelopes around skeletal grains and, probably, the growth of oncoids (Jones and Goodbody, 1985; Perry, 1998, 1999). These areas were characterized by bioclastic sediments with common cortoids, oncoids and rich associations of benthic foraminifers, calcareous algae (including dasycladacean and udoteacean green algae, and minor red algae), cyanobacteria (e.g., Osagia oncoids and encrustations), heterozoans (brachiopods, echinoderms, mollusks, bryozoans and calcareous sponges) and calcispheres. The pervasive occurrence of sponge spicule ghosts indicates that siliceous sponges probably also thrived in those environments. Although the euphotic zone in modern depositional environments may extend down to $40-50 \mathrm{~m}$, it is often limited to 20-30 m (Pomar, 2001; Wilson and Vecsei, 2005). The increase in turbidity linked to terrigenous and nutrient input may, however, reduce this limit to just a few metres.

In slightly deeper areas between the euphotic and oligophotic zone (which matches the mesophotic zone sensu Pomar, 2001), sediments consisted of bioclastic wackestones in which algae and larger foraminifers progressively disappear and heterozoans become more abundant with increasing water depths. In these areas, small-sized algal mounds developed. Heterozoan communities dominated by brachiopods, crinoids, bryozoans and calcareous demosponges flourished.

Generally in deeper environments, mud mounds developed as result of the colonization of the seafloor by microbial communities (with Tubiphytes and other scarce calcimicrobes) associated with metazoans such as Thartharella worms, bryozoans, calcareous inozoan and sphinctozoan sponges, siliceous sponges and crinoids. Micritic sediment formed as products of the life activity of such communities, or post-mortem processes (Pickard, 1996; Riding, 2000, among others) is volumetrically a major component of the mound core deposits (facies Md5). Algae occurred only locally within these mud mounds, probably when the actual sea bottom reached the lower limit of the photic zone. These environments distally passed into shaly argillaceous slopes and basinal deposits.

\section{Discussion}

The Las Llacerias Formation is characterized by very diverse biotic associations that have rarely been recorded in the older carbonate platform facies of the Valdeteja and Picos de Europa Formations. Moreover, the grain composition points to a shallow-water setting (Fig. 15). Significant differences with respect to previous carbonate systems are: 1) absence of ooids, 2) significant decrease in early marine cementation, 3 ) astonishing increase in micritized grains, and abundance of cortoids, lumps (formed by superficial micritization and by constructive micritic coating) and Osagia oncoids, 4) accumulation of organic mater, and 5) influx of siliciclastics during deposition. This shift in grain composition is thought to record major environmental changes, which affected the biotic communities and the carbonate factory at the base of the Kasimovian stage.

Comparing the geological scenarios of the Bashkirian-Moscovian carbonate shelf (Valdeteja and Picos de Europa Formations, Colmenero et al., 2002; Fernández et al., 2004; Bahamonde et al., 2007) and the Kasimovian thrust-top carbonate system (Las Llacerias Formation), only a major difference in nutrient levels appears as the strongest environmental factor that controlled the biotic composition. The skeletal grain types recorded in the platform-top successions of the previous carbonate shelf (Valdeteja and Picos de Europa Formation) and in the Las Llacerias Formation are dominated by photozoans (Bahamonde et al., 2000; Della Porta et al., 2002; Della Porta, 2003; Della Porta et al., 2006; Bahamonde et al., 2007), as may be expected for tropical Pennsylvanian warm-water carbonates, and mostly corresponds to the chlorozoan and chlorosponge associations (Beauchamp and Desrochers, 1997; James, 1997; Wahlman, 2002). These associations are present from Bashkirian-Moscovian and into Kasimovian times. In both cases, the common occurrence of stenohaline biota, including echinoderms, chaetetid sponges, corals and brachiopods, suggest normal salinity and open-marine conditions. Therefore, changes in temperature or salinity probably do not account for the shift in biotic associations from somewhat less diverse benthic communities during Bashkirian-Moscovian to the higher-diversity communities during the Kasimovian.

The major change in basin configuration, namely the rapid motion of the orogenic front that started from the latest Moscovian (late Myachkovian) and caused a very rapid narrowing of the marine basin and the tectonic uplift of nearby mountainous reliefs (Fig. 1C) seems to have played a key role. The hot-humid climatic conditions that are inferred for this area of Pangea (Tabor and Poulsen, 2008) would favour high rates of weathering and erosion of the newly created hinterland surrounding the marine basin (Figs. 1C and 14A), and the subsequent transport of sediments basinwards by large river discharge, presumably under monsoon conditions. Additionally, this freshwater discharge would also supply dissolved nutrients and organic carbon. Land-derived nutrients could have reached the SE area of the Picos de Europa during the deposition of the Las Llacerias Formation (late Myachkovian and early Kasimovian), because of the rapid narrowing and gradual filling of the marine basin (Fig. 1C). This was not the case earlier during Bashkirian and Moscovian times, when the foreland basin was deep and the carbonate platform was remote from the siliciclastics shed from deltaic systems and, thus, also remote from land-derived nutrients.

In the Las Llacerias Formation, facies criteria and the inferred biothic communities provide arguments that are in accordance with this scenario supporting both the existence of high nutrient levels and 


\begin{tabular}{l} 
INDEX Maximum abundance \\
Relatively common \\
Absent \\
Ooill abundace \\
Micriticed grains \\
Cortoids (micrite coated grains) \\
Osagia oncoids \\
Microborings \\
\hline Beresella, Divinella \\
Donezella \\
Praedonezella \\
Ungdarellids \\
Dasycladacean algae (Anthracoporella, \\
Bdoteacean phylloid algae \\
Bryozoans \\
Calcispheres and Penella \\
Girvanella-like incrustations \\
Rugose solitary corals \\
Rugose colonial corals \\
Syringoporid corals \\
Chaetetid sponges \\
Sphinctozoan sponges \\
Sponge spicules \\
Brachiopods
\end{tabular}

Fibrous, radiaxial fibrous, botryoidal cements $\square$

\begin{tabular}{l}
\hline Terrigenous input (silt to sand $Q$ grains, clay) \\
Organic mater
\end{tabular}

Fig. 15. Relative proportion of grains forming shallow-water subtidal deposits (platform-top and inner to mid-ramp settings) within 3 successive time intervals from Bashkirian to early Kasimovian in carbonate successions of Picos de Europa Province and Ponga-Cuera Unit.

the arrival of siliciclastic material shed from nearby continental areas. In addition, the lack of indicators of upwelling reinforces the hypothesis of the terrestrial source for the nutrients.

\subsection{Facies criteria}

1) The finer terrigenous content (clay, silt- to sand-sized quartz) throughout the Las Llacerias Formation and locally drifted plant remains was apparently provided by deltas and fan-deltas developed at the mouths of river systems draining the adjacent growing orogenic range to the east (Fig. 14A).

2) Shallow-water deposits of the Las Llacerias Formation are characterized by pervasive micritization and bioerosion affecting skeletal grains (facies A1, A2, A3 and B1). Biological and chemical alteration of skeletal grains (e.g., early micritization) is suggested to increase with eutrophic conditions (Wood, 1993; Kiene et al., 1995). Hallock (1988) demonstrated that in modern mesotrophic waters close to river mouths and in marine areas affected by currents of nutrient-rich waters (e.g., from the Mississippi delta to western and southern Florida), carbonate sand and gravel exhibiting biological alteration are abundant. Also Peterhänsel and Pratt (2001) postulated that the increase in the effects of bioeroders (skeletal micritization and bioerosion) in the Late Devonian carbonate platform of the Palliser Formation (Canadian Rocky Mountains) was linked to an increase in nutrient supply.

3) The common occurrence of cyanobacterial oncoids (Osagia) is considered as an indicator for high nutrient levels (Flügel, 2004). Moreover, constructional microbial encrustation and micritic envelopes forming cortoids, aggregates, which also contributed to the genesis of oncoids, is a further indicator for high nutrient levels (Peterhänsel and Pratt, 2001).

4) The dark colour characterizing the autochthonous carbonate deposits of the Las Llacerias Formation seems to have resulted from a high amount of non-degraded organic matter present within the sediments and visible in many thin sections (Figs. 8D and $13 \mathrm{~A}$ ). This may indicate high rates of primary production by photosynthesis leading to substantial production of organic matter, which is favoured by the availability of nutrients.

5) Dissolved silica resulting from the weathering of silicate rocks via riverine input is an important source for nutrients in modern oceans, particularly in tropical regions (Tréguer et al., 1995). Overall, the abundance of biogenic $\mathrm{SiO}_{2}$ and their diagenetic products are considered indicators of mesotrophic and eutrophic waters (Wood, 1993; Föllmi et al., 1994) and generally characterize deep-marine carbonate sediments and shallow-water carbonates on nutrient-rich carbonate shelves. In the Las Llacerias Formation there is a high degree of preservation of unaltered siliceous sponge spicules. Also, silicified skeletal grains are widespread in the outer and mid-ramp, including relatively shallow-water deposits.

\subsection{Biotic communities}

The fossil record may be disturbed by taphonomic processes and early and late diagenesis (Cherns and Wright, 2000; Flügel, 2004; Wright and Burgess, 2005). Thus, the applicability of actualism to unravelling the details of the composition and the structure of past biotic communities is not straightforward. Nevertheless, carbonate sediments can provide data that may help to make first-order reconstructions of past communities on the basis of detailed palaeontologic and microfacies analysis.

In the studied outcrops of the Las Llacerias Formation, the biotic communities recorded in the inner and mid-ramp deposits, which are rich in photozoans (algae and cyanobacteria) and foraminifers associated with crinoids and echinoids, brachiopods, bryozoans, calcareous sponges, mollusks and tabulate and rugose corals, may be comparable to the heterozoan-photozoan transition association that characterizes nutrient-rich (upper mesotrophic-eutrophic) warm to temperate modern shallow-water $(<50 \mathrm{~m})$ carbonate environments (Halfar et al., 2004, 2006).

Cyanobacteria and probable associated heterotrophic bacteria were widespread in these shallow-water realms as indicated by: 1) the pervasive micritization of skeletal grains, 2) the occurrence of constructional micritic envelopes and porostromate encrustations around grains, and Osagia oncoids with calcified filaments of Girvannella and Claracrusta, and 3) the occurrence of structures described as microbial fabrics in the various buildups described (facies Md1, Md2, Md3, Md4 and Md5). Microbially mediated carbonate precipitation, resulting in the formation of microbialites, is known to be enhanced by the presence of organic matter and alkaline metals in siliciclastics (Neuweiler et al., 1996; Dupraz and Strasser, 2002). 
Boundstones dominated by heterotrophic organisms and microbial-mud mounds are predicted to form in mesotrophic conditions under moderate- to low-energy conditions (Wood, 1993). Oxfordian coral-microbialite reefs including phototrophic-heterotrophic fauna and Terebella worms developed in environments moderately affected by terrigenous input and nutrient availability (Dupraz and Strasser, 2002). This fits the findings of the present paper, where presumably microbially precipitated micrite and the calcified worm tube Thartharella are common (facies Md1, Md3, Md4 and Md5).

Eugonophyllum and other phylloid algae are among the most abundant biota within the shallow subtidal deposits (facies B1 and B2) and frequently formed algal mounds (facies Md4). According to Suchy and West (2001), the growth of phylloid algae appears to coincide with high nutrient inputs, an interpretation supportive of our findings. Similarly, during the Holocene, the phylloid udoteacean alga Halimeda thrives and is known to build mounds (bearing certain similarities to the Palaeozoic phylloid algal mounds) in low-latitude areas of high nutrient levels, either from adjacent continental areas or from coastal settings influenced by upwelling (Hallock et al., 1988; Hine et al., 1988; Marshall and Davies, 1988; Roberts et al., 1988; Davies et al., 2004; Wilson and Vecsei, 2005).

The high amount of ghosts of sponge spicules associated with shallow-marine organisms (e.g., phylloid algae) indicates that siliceous sponges were obviously abundant in the euphotic zone. That contrasts to modern examples where sponges and silica-rich sediments are restricted to deep-water environments (Hartman, 1981; Maliva et al., 1989; Rosales et al., 1995). Other examples of siliceous sponges in nearshore areas are reported from Pennsylvanian spicular flints (Lane, 1981; Carlson, 1994). In these examples, nutrients originating from riverine input played a key role in the establishment of siliceous sponges.

Fishes thrived and were probably abundant, as indicated by the findings of fish bones, teeth and scales in outcrop and in dissolved rock samples, adding another indirect criteria of elevated primary productivities and high nutrient levels.

Intervals with high siliciclastic content are dominated by heterotrophic faunas with very abundant, small but diverse brachiopods, crinoids, calcareous sponges (mostly sphinctozoans), bryozoans, small-sized solitary Cyathaxonia corals and gastropods. These probably record eutrophic conditions coinciding with periods of high terrigenous input and probably turbid waters.

\subsection{Absence of upwelling indicators}

Upwelling of deep cold water is one of the mechanisms that can account for the nutrient enrichment of surface waters. However, the configuration of the marine basin studied, with narrow elongated troughs and ridges, oriented parallel to the Variscan thrusts, within a progressively narrowing and shallowing foreland basin, was not suitable for widespread upwellings. Although minor turnover and vertical mixing of waters in these partially isolated troughs could have been a considerable source of nutrients during 4th-5th order galcioeustatic sea-level rises, no evidence of cold, nutrient-rich waters affecting the inner- and mid-ramp zones such as phosphatic layers is recorded.

The skeletal components of the inner and mid-ramp, typical for the chlorosponge association (see above), and the abundance of skeletal grains such as phylloid algal thalli, sphinctozoan and inozoan sponges, indicate a prevalence of warm waters down to considerable water depths. In addition, the recorded biotic associations differ from those described in other Carboniferous carbonate settings where upwelling conditions have been invoked (Brandley and Krause, 1997; Martindale and Boreen, 1997; Samankassou, 2002) and from those characterizing cold-water and temperate shelf carbonates that might have been expected if upwelling processes might had occurred (compare with Beauchamp, 1994; Beauchamp and Desrochers, 1997).

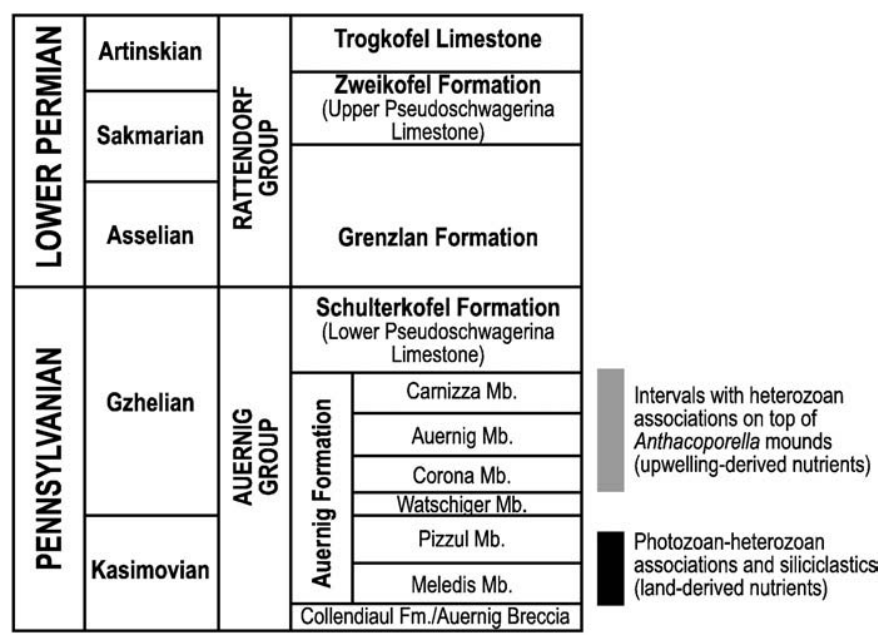

Fig. 16. Stratigraphy of Pennsylvanian-Early Permian succession in Carnic Alps showing stratigraphic interval of Auernig Group mentioned in text (modified from Samankassou, 2002).

\subsection{The Auernig Formation, Carnic Alps, Austria: an analogue case?}

High-diversity biotic associations were reported from two Kasimovian-Gzhelian intervals within the Auernig cyclothems of the Carnic Alps, Austria-Italy (see Fig. 1B for location). The first interval corresponds to the basal Auernig sequences deposited discordantly upon the underlying Devonian basement, which displays significant relief resulting from the Variscan Orogeny (Forke and Samankassou, 2000) (Fig. 16). The sequences vary laterally in thickness, and include dark-grey to brown limestone beds, are rich in siliciclastics, and show a high-diversity biotic association of Anthracoporella, phylloid algae, echinoderms, corals, sponges, bryozoans and brachiopods (Forke and Samankassou, 2000). The high diversity of algae and suspension feeders may be linked to high nutrient levels resulting from reworking and remobilisation of siliciclastics.

The second interval corresponds to the upper members of the Auernig Group (Fig. 16) and the high-diversity associations appear on top of distinct Anthracoporella buildups (Samankassou 2002). These levels are characterized by high-diversity associations of heterozoans that are interpreted to record periodic upwelling of cool, nutrient-rich water into a shallow-water setting (Samankassou, 2002).

In contrast to the cool-water scenario drawn from the heterozoanrich faunal associations of the upper members of the Auernig Group, the shallow-water deposits (inner and mid-ramp) of the Las Llacerias Formation exhibit a mixed photozoan-heterozoan association that resembles the benthic communities recorded in the basal Auernig sequences. Land-derived nutrient input (from deltaic siliciclastics), interpreted as the main source and triggering factor in the Las Llacerias Formation and the lower part of the Auernig Group, was considered only a minor factor in the upper part of the Auernig Group (Samankassou, 2002). The difference in nutrient source between the Las Llacerias Formation and the lower part of the Auernig Group on the one hand (land-derived), and the upper part of the Auernig Group on the other (upwelling-derived), and the cooler water temperature linked to the latter may explain why the two cases differ in their respective biotic associations.

\section{Conclusions}

The Pennsylvanian (lower Kasimovian) Las Llacerias Formation represents thrust-top carbonate ramps developed upon small tectonic uplifts during the incipient thrusting of an antecedent extensive flattopped carbonate platform (Bashkirian-Moscovian). It occurred within a narrowed marine foreland basin located in the palaeoequatorial humid 
belt on the east coast of Pangea. The rich benthic communities recorded in the Las Llacerias Formation carbonates are an exceptional case that is rarely documented in coeval deposits worldwide.

The shallow-water, well-illuminated and low-energy realms of these carbonate systems were characterized by the occurrence of decimetre- to metre-sized photozoan (Anthracoporella and phylloid algae) mounds and metazoan (chaetetids, syringoporids and branching colonial rugose corals) reef-mounds embedded within black, biota-rich nodular wackestones to packstones with a mixed photozoan-heterozoan biota. In the deep parts of the ramps, the bioclastic grains consist of heterozoan associations and mud mounds (Md5) dominated by microbial communities with minor contribution of metazoans (mostly bryozoans, sphinctozoan and inozoan sponges, worms and Tubiphytes).

The growth of these high-diversity benthic communities coincides with a significant increase in terrigenous influx and hence nutrient supply from terrestrial runoff that was favoured by the changing tectonic configuration and the humid climatic conditions. Considerable land-derived nutrient influx from river discharges that was draining the adjacent growing orogenic chain into the narrow marine foreland basin led to mesotrophic and, locally, to eutrophic conditions in the surface waters. These high nutrient levels are considered to be the main factor that controlled the establishment of the diverse shallow-water communities that produced the grain types forming the carbonate facies. This scenario presumably favoured high productivity, which also led to abundant non-degraded organic matter that is responsible for the pervasive dark colour of these carbonates.

The scenario for the Las Llacerias Formation is supported by a similar trend in the lower part of the Auernig Group of the Carnic Alps, where biotic communities were controlled by land-derived nutrients, eroded from the underlaying beds.

The influence of land versus upwelling-derived nutrients is commonly difficult to discriminate. The Las Llacerias example is thus a case that potentially may help to better distinguish between biotic communities controlled by land-derived versus upwellingderived nutrients in the fossil rock record, particularly in areas where the tectonic context is not well constrained.

\section{Acknowledgements}

The authors acknowledge financial support of the Ministerio de Ciencia y Tecnología of Spain (grants \# DGICYT-PB-95/1040, MCT00BTE-0580 and MCT-03-BTE 01012), from FICYT of the Regional Government of Asturias and European Regional Development Fund (grant \# IB05-087) and from the Swiss National Science Foundation (grant \# 200021-107505). S. Rodríguez and D. García-Bellido (Madrid, Spain) gave advice on the taxonomy of corals and calcareous sponges, respectively, and M. L. Martínez-Chacón (Oviedo, Spain) on brachiopods. J. Sanz (La Coruña, Spain) and S. Blanco-Ferrera (Oviedo, Spain) provided data about silicified foraminifers and fish scales in dissolved limestone samples. V. P. Wright and G. Della Porta (Cardiff, UK) are thanked for their comments on an earlier draft of the manuscript. The authors also would like to thank Luis Pomar, Philip H. Heckel and Finn Surlyk for their constructive reviews of the manuscript.

\section{References}

Aigner, T., 1985. Storm depositional systems. Dynamic stratigraphy in modern and ancient shallow-marine sequences. In: Friedman, G.M., Neugebauer, H.J., Seilacher, A. (Eds.), Lecture Notes in Earth Sciences, vol. 3, pp. 1-174.

Bahamonde, J.R., Vera, C., Colmenero, J.R., 2000. A steep-fronted Carboniferous carbonate platform: clinoformal geometry and lithofacies (Picos de Europa Region, NW Spain). Sedimentology 47, 645-664.

Bahamonde, J.R., Merino-Tomé, O.A., Heredia, N., 2007. Pennsylvanian microbial boundstone-dominated carbonate shelf developed in a distal foreland margin (Picos de Europa Province, NW Spain). Sedimentary Geology 198, 167-193.

Beauchamp, B., 1994. Permian climatic cooling in the Canadian Arctic. Special PaperGeological Society of America 288, 229-245.
Beauchamp, B., Desrochers, A., 1997. Permian warm- to very cold-water carbonates and cherts in northwest Pangea. In: James, N.P., Clarke, J.A.D. (Eds.), Cool-water Carbonates. Special Publication, vol. 56. SEPM (Society for Sedimentary Geology), pp. 327-347.

Birkeland, C., 1977. The importance of rate of biomass accumulation in early successional stages of benthic communities to the survival of coral recruits. Proc. 3rd Int. Coral Reef Symposium, Miami, 1977, vol. 1, pp. 16-21.

Bosence, D., 2005. A genetic classification of carbonate platforms based on their basinal and tectonic settings in the Cenozoic. Sedimentary Geology 175, 49-87.

Brandley, R.T., Krause, F.F., 1997. Upwelling, thermoclines and wave-sweeping on an equatorial carbonate ramp: Lower Carboniferous of Western Canada. In: James, N.P., Clarke, J.A.D. (Eds.), Cool-water Carbonates. Special Publication, vol. 56. SEPM (Society for Sedimentary Geology), pp. 365-390.

Burchette, T.P., Wright, V.P., 1992. Carbonate ramp depositional systems. Sedimentary Geology 79, 3-57.

Carannante, G., Esteban, M., Milliman, J.D., Simone, L., 1988. Carbonate lithofacies as palaeolatitude indicators: problems and limitations. In: Nelson, C.S. (Ed.), Non-Tropical Shelf Carbonates, Modern and Ancient. Sedimentary Geology, 60, pp. 333-346.

Carannante, G., Graziano, R., Ruberti, D., Simone, L., 1997. Upper Cretaceous temperatetype open shelves from northern (Sardinia) and southern (Apennines-Apulia) Mesozoic Tethyan margins. In: James, N.P., Clarke, J.A.D. (Eds.), Cool-water Carbonates. Special Publication, vol. 56. SEPM (Society for Sedimentary Geology), pp. 309-325.

Carlson, E.H., 1994. Paleoshoreline patterns in the transgressive-regressive sequences of Pennsylvanian rocks in the northern Appalachian Basin, U.S.A. Sedimentary Geology 93, 209-222.

Chave, K.E., 1967. Recent carbonate sediments- an unconventional view. Geological Education 7, 200-204.

Cherns, L., Wright, V.P., 2000. Missing mollusks as evidence of large scale, early aragonite dissolution in a Silurian sea. Geology 28, 791-794.

Coffey, B.P., Read, J.F., 2007. Subtropical to temperate facies from a transition zone, mixed carbonate-siliciclastic system, Palaeogene, North Carolina, USA. Sedimentology 54, 339-365.

Colmenero, J.R., Fernández, L.P., Moreno, C., Bahamonde, J.R., Barba, P., Heredia, N., González, F., 2002. Carboniferous. In: Gibbons, W., Moreno, M.T. (Eds.), The Geology of Spain. Geological Society, London, pp. 93-116.

Connolly, W.M., Lambert, L.L., Stanton Jr., J., 1989. Paleoecology of Lower and Middle Pennsylvanian (Middle Carboniferous) in North America. Facies 20, 139-168.

Cózar, P., Merino-Tomé, O., Villa, E., 2007. New data (smaller foraminifera and correlation with depositional sequences) on the Las Llacerias section (Upper Pennsylvanian, Cantabrian Mountains, Spain). Facies 53, 427-450.

Davies, P.J., Braga, J., Lund, M., Webster, J.M., 2004. Holocene deep water algal buildups on the eastern Australian Shelf. Palaios 19, 598-609.

Della Porta, G., 2003. Depositional anatomy of a Carboniferous high-rising carbonate platform (Cantabrian Mountains, NW Spain). Ph.D. Thesis, Vrije Universiteit, Amsterdam, The Netherlands, pp. 1-250.

Della Porta, G., Kenter, J.A.M., Immenhauser, A., Bahamonde, J.R., 2002. Lithofacies character and architecture across a Pennsylvanian inner-platform transect (Sierra de Cuera, Asturias, Spain). Journal of Sedimentary Research 72, 898-916.

Della Porta, G., Villa, E., Kenter, J.A.M., 2006. Facies distribution of fusulinida in a Bashkirian-Moscovian (Pennsylvanian) carbonate platform top (Cantabrian Mountains, NS Spain). Journal of Foraminiferal Research 35, 344-367.

Dupraz, C., Strasser, A., 2002. Nutritional modes in coral-microbialite reefs (Jurassic, Oxfordian, Switzerland): evolution of trophic structure as a response to environmental change. Palaios 17, 449-471.

Enos, P., Moore, C.H., 1983. Fore-reef slope environments. In: Scholle, P.A., Bebout, D.G., Moore, C.H. (Eds.), Carbonate Depositional Environments. Memoir, vol. 33. American Association of Petroleum Geologists, pp. 507-537.

Faulkner, T.J., 1988. The Shipway Limestone of Gower: sedimentation on a stormdominated early Carboniferous ramp. Geological Journal 23, 85-100.

Fernández, L.P., Bahamonde, J.R., Barba, P., Colmenero, J.R., Heredia, N., RodríguezFernández, L.R., Salvador, C.I., Sánchez de Posada, L.C., Villa, E., Merino-Tomé, O.A., Motis, K., 2004. La sucesión sinorogénica de la Zona Cantábrica. In: Vera, J.A. (Ed.), Geología de España. Sociedad Geológica España, Madrid, pp. 34-42.

Flügel, E., 1982. Microfacies Analysis of Limestones. Springer, Berlin, pp. 1-633.

Flügel, E., 2004. Microfacies of Carbonate Rocks, Analysis, Interpretation and Application. Springer, Berlin, pp. 1-976.

Föllmi, K.B., Weissert, H., Bisping, M., Funk, H., 1994. Phosphogenesis, carbon-isotope stratigraphy, and carbonate platform evolution along the Lower Cretaceous northern Tethyan margin. Geological Society of America Bulletin 106, 729-746.

Forke, H.C., Samankassou, E., 2000. Biostratigraphical correlation of late Carboniferous (Kasimovian) sections in the Carnic Alps (Austria/Italy): integrated paleontological data, facies, and discussion. Facies 42, 177-210.

Forsythe, G.T.W., 2003. A new synthesis of Permo-Carboniferous phylloid algal reef ecology. Selected Pennsylvanian algal-dominated buildups in Eastern Kansas, Midcontinent, U.S.A. In: Ahr, W., (Mitch) Harris, P.M., Morgan, W.A., Somerville, I.D. (Eds.), Permo-Carboniferous Carbonate Platforms and Reefs. Special Publication, 78. SEPM (Society for Sedimentary Geology), PP. 171-188.

Golonka, J., Ross, M.I., Scotese, C.R., 1994. Phanerozoic paleoclimatic modeling maps. In: Embry, A.F., Beauchamp, B., Glass, D.J. (Eds.), Pangea: Global Environment and Resources. Memoir, vol. 17. Canadian Society of Petroleum Geologists, pp. 1-47.

Gradstein, F.M., Ogg, J.G., Smith, A.G., Bleeker, W., Lourens, L.J., 2004. A new geologic time scale, with special reference to Precambrian and Neogene. Episodes 2, 83-100.

Halfar, J., Godinez-Orta, L., Mutti, M., Valdez-Holguin, J.E., Borges, J.M., 2004. Nutrient and temperature controls on modern carbonate production: an example from the Gulf of California, Mexico. Geology 32, 213-216. 
Halfar, J., Godinez-Orta, L., Mutti, M., Valdez-Holguin, J.E., Borges, J.M., 2006. Carbonates calibrated against oceanographic parameters along a latitudinal transect in the Gulf of California, Mexico. Sedimentology 53, 297-320.

Hallock, P., 1987. Fluctuations in the trophic resource continuum: a factor in global diversity cycles? Paleoceanography 2, 457-471.

Hallock, P., 1988. The role of nutrient availability in bioerosion: consequences to carbonate buildups. Palaeogeography, Palaeoclimatology, Palaeoecology 63, 275-291.

Hallock, P., 2001. Coral reefs, carbonate sedimentation, nutrients, and global change. In: Stanley, G.D. (Ed.), The History and Sedimentology of Ancient Reef Ecosystems. Kluwer Academic/Plenum Publishers, New York, pp. 387-427.

Hallock, P., Hine, A.C., Vargo, G.A., Elrod, J.A., Walter, C.J., 1988. Platforms of the Nicaraguan Rise: examples of the sensitivity of carbonate sedimentation to excess trophic resources. Geology 16, 1104-1107.

Handford, C.R., 1986. Facies and bedding sequences in shelf-storm-deposited carbonates; Fayetteville and Pitkin Limestone (Mississippian), Arkansas. Journal of Sedimentary Petrology 56, 123-137.

Hartman, W.D., 1981. Form and distribution of silica sponges. In: Simpson, T.L., Volcani, B.E. (Eds.), Silicon and Siliceous Structures in Biological Systems. Springer, New York, pp. 453-493.

Heckel, P.H., Alekseev, A.S., Barrick, J.E., Boardman, D.R., Goreva, N.V., Nemyrovska, T.I., Ueno, K., Villa, E., Work, D.M., 2008. Cyclothem ["digital”] correlation and biostratigraphy across the Moskovian-Kasimovian and Kasimovian-Gzhelian Stage boundary interval (Middle-Upper Pennsylvanian Series) in North America and Eurasia. Geology 35, 607-610.

Herbig, H.-G., Bender, P.M., 1992. A eustatically driven calciturbidite sequence from the Dinantian II of the eastern Rheinisches Schiefergebirge. Facies 27, 245-262.

Herbig, H.-G., Mamet, B., 1994. Hydraulic sorting of microbiota in calciturbidites: a Dinantian case study from the Rheinisches Schiefergebirge, Germany. Facies 31, 93-104.

Hine, A.C., Hallock, P., Harris, M.W., Mullins, H.T., Belknap, D.F., Jaap, W.C., 1988. Halimeda bioherms along an open seaway: Miskito Channel, Nicaraguan Rise, SW Caribbean Sea. Coral Reefs 6, 173-178.

James, N.P., 1997. The cool-water carbonate depositional realms. In: James, N.P., Clarke, J.A.D. (Eds.), Cool-water Carbonates. Special Publication, vol. 56. SEPM (Society for Sedimentary Geology), pp. 1-20.

Jeffery, D.L Stanton, RJ. 1996. Biotic gradients on a homoclinal ramp, the Alamogordo Member of the Lake Valley Formation, Lower Misssissippian, New Mexico, USA. In: Strogen, P., Somerville, J.D., Jones, G.L. (Eds.), Recent Advances in Lower Carboniferous Geology. Special Publication, vol. 107. Geological Society of London, pp. 111-126.

Jones, B., Goodbody, Q.H., 1985. Oncolites from a shallow lagoon, Grand Cayman Island. Bulletin Canadian Petroleum Geology 32, 254-260.

Julivert, M., 1971. Décollement tectonics in the Variscan Cordillera of the northwest Spain. American Journal of Sciences 270, 1-29.

Kiene, W.E., Vogel, K.P., Gektidis, M., Radtke, G., Golubic, S., Le Campion, T., 1995. Investigations of microbial organisms on reefs (abstract). Second European Meeting of the International Society of Reef Studies. Newcastle Sept. 1995. University of Newcastle.

Krainer, K., 1995. Anthracoporella mounds in the Late Carboniferous Auernig Group, Carnic Alps (Austria). Facies 32, 195-214

Lane, N.G., 1981. A nearshore sponge spicule mat from the Pennsylvanian of westcentral Indiana. Journal of Sedimentary Petrology 51, 197-202.

Lavoie, D., 1995. A late Ordovician high-energy temperate-water carbonate ramp, southern Quebec: implications fro Late Ordovician oceanography. Sedimentology $42,95-116$

Lees, A., 1975. Possible influence of salinity and temperature in modern shelf carbonate sedimentation. Marine Geology 19, 159-198.

Lees, A., Buller, A.T., 1972. Modern temperate-water and warm-water shelf carbonate sediments contrasted. Marine Geology 13, 1767-1773.

Lees, A., Miller, J., 1995. Waulsortian banks. In: Monty, C.L.V., Bosence, D.W.J. (Eds.), Carbonate Mud Mounds. Their Origin and Evolution. Special Publication, vol. 23. International Association of Sedimentologists, pp. 191-272.

Leonard, J.E., Cameron, B., Pilkey, O.H., Friedman, G.M., 1981. Evaluation of cold-water carbonates as a possible paleoclimatic indicator. Sedimentary Geology 28, 1-28.

Lukasik, J., James, N.P., McGrowan, B., Bone, Y., 2000. An epeiric ramp: Low energy, coolwater carbonate facies in a Tertiary inland sea, Murray Basin, South Australia. Sedimentology 47, 851-881.

Maliva, R.G., Knoll, A.H., Siever, R., 1989. Secular change in chert distribution: a reflection of evolving biological participation in the silica cycle. Palaios 4, 519-532.

Mamet, B., Villa, E., 2004. Calcareous marine algae from the Carboniferous (MoscovianGzhelian) of the Cantabrian Zone (NW Spain). Revista Española de Paleontología 19, 151-190.

Marquínez, J., 1989. Mapa Geológico de la Región del Cuera y Picos de Europa (Cordillera Cantábrica, NW de España). Trabajos Geología, Universidad de Oviedo 18,137-144.

Marshall, J.F., Davies, P.J., 1988. Halimeda bioherms of the northern Great Barrier Reef. Coral Reefs 6, 139-148.

Martínez García, E., Villa, E., 1999. Edad de los primeros signos de actividad tectónica en el Carbonífero superior de los Picos de Europa (Asturias, NO de España). Trabajos Geología, Univ Oviedo 21, 229-238.

Martindale, W., Boreen, T.D., 1997. Temperature-stratified Mississippian carboantes as hydrocarbon reservoirs -examples from the foothills of the Canadian Rockies. In: James, N.P., Clarke, J.A.D. (Eds.), Cool-water Carbonates. Special Publication, vol. 56. SEPM (Society for Sedimentary Geology), pp. 391-409.

Merino-Tomé, O.A., 2004. Estratigrafía, Sedimentologíay evolución tectono-sedimentaria de las sucesiones estefanienses en la Región de Picos de Europa. Ph.D. Thesis, Universidad de Salamanca, Spain.
Merino-Tomé, O.A., Bahamonde, J.R., Fernández, L.P., Colmenero, J.R., 2007. Facies architecture and cyclicity of a Upper Carboniferous carbonate ramp developed in a Variscan piggy-back basin (Cantabrian Mountains, NW Spain). In: Nichols, G., Willians, E., Paola, C. (Eds.), Sedimentary Processes, Environments and Basins: a Tribute to Peter Friend. Special Publication, vol. 38. International Association of Sedimentologists, pp. 183-217.

Merino-Tomé, O.A., Bahamonde, J.R., Colmenero, J.R., Heredia, N., Villa, E., Farias, P., 2009. Emplacement of the imbricate system of the Cuera Unit and the Picos de Europa Province in the core of the Ibero-Armorican Arc (N Spain). New precissions on the timing of the arc closure. Geological Society of America Bulletin 121, 729-751, doi:10.1130/B26366.1.

Miller, K.B., West, R.R., 1997. Growth-interruption surfaces within chaetetid skeletons: records of physical disturbance and depositional dynamics. Lethaia 29, 289-299.

Mulder, T., Alexander, J., 2001. The physical character of subaqueous sedimentary density flows and their deposits. Sedimentology 48, 269-300.

Mutti, M., Hallock, P., 2003. Carbonate systems along nutrient and temperature gradients: some sedimentological and geochemical constraints. International Journal of Earth Sciences (Geologische Rundschau) 92, 465-475.

Narding, T.R., Hein, F.J., Gorsline, D.S., Edwards, B.D., 1979. A review of mass movement processes, sediment and acoustic characteristics, and contrasts in slope and baseof-slope systems versus canyon-fan-basin floor systems. In: Doyle, L.J., Pilkey, O.H. (Eds.), Geology of Continental Slopes. Special Publication, vol. 27. SEPM (Society for Sedimentary Geology), pp. 61-73.

Nelson, C.S., 1988. An introductory perspective on non-tropical shelf carbonates. Sedimentary Geology 60, 3-12.

Neuweiler, F., Reitner, J., Arp, G., 1996. Controlling factors and environmental significance of organomicrite production and buildup development. Göttinger Arbeiten Geologie Paläontologie, Sonderband 2, 185-192.

Pérez-Estaún, A., Bastida, F., Alonso, J.L., Marquínez, J., Aller, J., Álvarez-Marrón, J., Marcos, A., Pulgar, J.A., 1988. A thin-skinned tectonics model for an arcuate fold and thrust belt: the Cantabrian Zone (Variscan Ibero-Armorican Arc). Tectonics 7, 517-537.

Perry, C.T., 1998. Grain susceptibility to the effects of microboring: implications for the preservation of skeletal carbonates. Sedimentology 45, 39-51.

Perry, C.T., 1999. Biofilm-related calcification, sediment trapping and constructive micrite envelopes: a criterion of ancient grass-bed environments? Sedimentology 46, 33-46.

Peterhänsel, A., Pratt, B.R., 2001. Nutrient-triggered bioerosion on a giant carbonate platform masking the postextinction Famennian benthic community. Geology 29, 1079-1082.

Pickard, N.A.H., 1996. Evidence for microbial influence on the development of Lower Carboniferous buildups. In: Strogen, P., Somerville, I.D., Jones, G.Ll. (Eds.), Recent Advances in Lower Carboniferous Geology. Special Publication, vol. 107. Geological Society of London, pp. 65-82.

Pomar, L., 2001. Types of carbonate platforms: a genetic approach. Basin Research 13 313-344.

Pomar, L., Brandano, M., Westphal, H., 2004. Environmental factors influencing skeletal grain sediment associations: a critical review of Miocene examples from western Mediterranean. Sedimentology 51, 627-651.

Postma, G., 1990. Depositional architecture and facies of rivers and fan deltas: a synthesis. In: Colella, A., Prior, D.B. (Eds.), Coarse-grained Deltas. Special Publication, vol. 10. International Association of Sedimentologists, pp. 13-27.

Reitner, J., Neuweiler, F., 1995. Mud Mounds: a polygenic spectrum of fine-grained carbonate buildups. Facies 32, 1-70.

Riding, R., 1993. Shamovella obscura: the correct name for Tubiphytes obscurus (Fossil) Taxon 42, 71-73

Riding, R., 2000. Microbial carbonates: the geological record of calcified bacterial-algal mats and biofilms. Sedimentology 47 (Suppl. 1), 179-214.

Roberts, H.H., Aharon, P., Phipps, C.V., 1988. Morphology and sedimentology of Halimeda bioherms from the eastern Java Sea, Indonesia. Coral Reefs 6, 161-172.

Rodríguez, S., Ramírez, C., 1987. Los siringopóridos de la sección de la playa de la Huelga (Carbonífero, Asturias, Noroeste de España). Boletín de la Real Sociedad Española de Historia Natural (Geol.) 83, 57-82.

Rosales, I., Mehl, D., Fernández-Mendiola, P.A., García-Modéjar, J., 1995. An unusua poriferan community in the Albian of Islares (north Spain): palaeoenvironmental and tectonic implications. Palaeogeography, Palaeoclimatology, Palaeoecology 119, 47-61.

Samankassou, E., 1997. Paleontological response to sea-level changes: the distribution of fauna and flora in cyclothems from the Lower Pseudoschwagerina Limestone (Latest Carboniferous, Carnic Alps, Austria). Geobios 30, 785-796.

Samankassou, E., 1998. Skeletal framework mounds of dasycladacean alga Anthracoporella, Upper Paleozoic, Carnic Alps, Austria. Palaios 13, 297-300.

Samankassou, E., 1999. Drowning of algal mounds: records from the Upper Carboniferous Lower Pseudoschwagerina Limestone, Carnic Alps, Austria. Sedimentary Geology 127, 209-220.

Samankassou, E. 2002. Cool-water carbonates in a paleoequatorial shallow-wate environment: the paradox of the Auernig cyclic sediments (Upper Pennsylvanian, Carnic Alps, Austria-Italy). Geology 30, 655-658.

Samankassou, E., 2003. Upper Carboniferous-Lower Permian buildups of the Carnic Alps, Austria-Italy. In: Ahr, W.M., Harris, P.M., Morgan, W.A., Somerville, I.D. (Eds.), Permo-Carboniferous Carbonate Platforms and Reefs. Special Publication, vol. 56. SEPM (Society for Sedimentary Geology), pp. 201-217.

Samankassou, E., West, R.R., 2002. Construction versus accumulation in phylloid alga mounds: an example of small constructed mound in the Pennsylvanian of Kansas, U.S.A. Palaeogeography, Palaeoclimatology, Palaeoecology 185, 379-389.

Sami, T., Desrochers, A., 1992. Episodic sedimentation on an Early Silurian, stormdominated carbonate ramp, Becscie and Merrimack formations, Anticosti Island, Canada. Sedimentology 39, 355-381. 
Schlager, W., 2005. Carbonate sedimentology and sequence stratigraphy. Concepts in Sedimentology and Paleontology, vol. 8. SEPM (Society for Sedimentary Geology), pp. 1-200.

Somerville, I.D., Rodríguez, S., 2007. Rugose coral associations from the Late Viséan of Western Tethys: examples from Ireland, Britain and Spain. Schriftenreihe der Erdwissenschaftlichen Kommissionen 17, 329-351.

Somerville, I.D., Strogen, P., 1992. Ramp sedimentation in the Dinantian limestones of the Shannon Trough, Co. Limerick, Ireland. Sedimentary Geology 79, 59-75.

Soreghan, G.S., Giles, K.A., 1999. Facies character and stratal responses to accomodation in Pennsylvanian bioherms, Western Orogrande Basin, New Mexico. Journal of Sedimentary Research 69, 893-908.

Suchy, D.R., West, R.R., 2001. Chaetetid buildups in a Westphalian (Desmoinesian) cyclothem in Southeastern Kansas. Palaios 16, 425-443.

Tabor, N.J., Poulsen, C.J., 2008. Palaeoclimate across the Late Pennsylvanian-Early Permian tropical palaeolatitudes: a review of climate indicators, their distribution, and relation to palaeophysiographic climate factors. Palaeogeography, Palaeoclimatology, Palaeoecology $268,293-310$

Tréguer, P., Nelson, D.M., Van Bennekom, A.J., DeMaster, D.J., Leynaert, A., Queguiner, B. 1995. The silica balance in the world ocean: a reestimate. Science 268, 375-379.

Tucker, M.E., Wright, V.P., 1990. Carbonate Sedimentology. Blackwell Science, pp. 1-482.

van Ginkel, A.C., Villa, E., 1999. Late Fusulinellid and early Schwagerinid foraminifera: relationships and occurrences in the Las Llacerias section (Moscovian/Kasimovian), Cantabrian Mountains, Spain. Journal of Foraminiferal Research 29, 263-290.

Vecsei, A., 2003. Nutrient control of the global occurrence of isolated carbonate banks. International Journal of Earth Sciences (Geologische Rundschau) 92, 476-481.
Villa, E., and Task Group, 2007. Progress Report of the Task Group to establish the Moscovian-Kasimovian and Kasimovian-Gzhelian boundaries, Newsletter on Carboniferous Stratigraphy, v. 25, p. 7-8.

Wendt, J., Kaufmann, B., Belka, Z., 2001. An exhumed Paleozoic underwater scenery: the Visean mud mounds of the eastern Anti-Atlas (Morocco). Sedimentary Geology $145,215-233$.

West, R.R., 1988. Temporal reef changes in Carboniferous reef mound communities. Palaios 3, 152-169.

West, R.R., Clark, G.R., 1984. Paleobiology and biological affinities of Paleozoic chaetetids. Paleontographica Americana 54, 337-348.

Wahlman, G., 2002. Upper Carboniferous-Lower Permian (Bashkirian-Kungurian) mounds and reefs. In: Kiessling, W., Flügel, E., Golonka, J. (Eds.), Phanerozoic Reef Patterns. Special Publication, vol. 72. SEPM (Society for Sedimentary Geology), pp. 271-338.

Wilson, J.L., 1969. Microfacies and sedimentary structures in deeper-water lime mudstones. In: Friedman, G.H. (Ed.), Depositional Environments in Carbonate Rocks. Special Publication, vol. 14. SEPM (Society for Sedimentary Geology), pp. 4-19.

Wilson, M.E.J., Vecsei, A., 2005. The apparent paradox of abundant foramol facies in low latitudes: their environmental significance and effect on platform development. Earth Science Reviews 69, 133-168.

Wood, R., 1993. Nutrients, predation and the history of reef building. Palaios 8, 526-543.

Wright, V.P., 1986. Facies sequences on a carbonate ramp: the carboniferous limestone of South Wales. Journal of Sedimentary Petrology 33, 221-241.

Wright, V.P., Burgess, P.M., 2005. The carbonate factory continuum, facies mosaics and microfacies: and appraisal to some of the key concepts underpinning carbonate sedimentology. Facies 51, 17-23. 